\title{
Do Public Fund Windfalls Increase Corruption? Evidence from a Natural Disaster
}

\author{
Elena Nikolova ${ }^{a}$
}

\author{
Nikolay Marinov ${ }^{\mathrm{b}}$ \\ 68131 Mannheim A5-6, Germany
}

October 5, 2016

\begin{abstract}
We show that unexpected financial windfalls increase corruption in local government. Our analysis uses a new data set on flood-related transfers, and the associated spending infringements, which the Bulgarian central government distributed to municipalities following torrential rains in 2004 and 2005. Using information from the publicly available audit reports we are able to build a unique objective index of corruption. We exploit the quasi-random nature of the rainfall shock (conditional on controls for ground flood risk) to isolate exogenous variation in the amount of funds received by each municipality. Our results imply that a $10 \%$ increase in the per capita amount of disbursed funds leads to a $9.8 \%$ increase in corruption. We also present suggestive evidence that more corrupt mayors anticipated punishment by voters and dropped out of the next election race. Our results highlight the governance pitfalls of non-tax transfers, such as disaster relief or assistance from international organizations, even in moderately strong democracies.
\end{abstract}

Keywords: corruption, natural disasters, governance JEL codes: D73, H71, P26

\footnotetext{
${ }^{a}$ Research Fellow, Central European Labour Studies Institute, Slovakia and associated researcher, IOS Regensburg, Germany. Email: nikolova.ele@gmail.com. We would like to thank Erik Berglöf, Rikhil Bhavnani, Simeon Djankov, Sergei Guriev, Stephan Litschig, Ivan Penkov, Grigore Pop-Eleches, Sandra Sequeira and conference participants at the 2015 Annual Meeting of the European Public Choice Society, Groningen, the 2015 American Political Science Association, San Francisco and seminar participants at Brunel, King's College workshop on corruption, and LSE for useful comments, and Erik Berglöf and Stefka Slavova for help with obtaining Bulgarian rainfall data. We thank the Council for European Research at Yale University for support at the early stages of the research, and the NGO Links Sofia for some data collection. Daniel Bierbaumer, Milena Djourelova and Francesca Dalla Pozza provided excellent research assistance. The views expressed in this paper are those of the authors only (in a personal capacity) and not necessarily of the EBRD.

${ }^{\mathrm{b}}$ Professor, Political Science, University of Mannheim. Email: marinov@sowi.uni-mannheim.de.
} 


\section{Introduction}

What are the governance consequences of non-resource windfalls, such as natural disaster relief? Scholars have studied other financial windfalls, coming to varying conclusions. One strand of the literature has related non-tax wealth to weakened democratic institutions (Gervasoni, 2010; Jensen \& Wantchekon, 2004; Ramsay, 2011), corruption (Ahmed, 2013; Caselli \& Michaels, 2013; Vicente, 2010) and poor quality of politicians (Brollo, Nannicini, Perotti, \& Tabellini, 2013). In contrast, a different body of work has questioned these effects, suggesting that some countries may in fact experience a "resource blessing" (Dunning, 2008; Haber \& Menaldo, 2011), or that the deterioration in leader accountability following a resource boom may be short-lived. ${ }^{1}$ Work on foreign aid similarly debates whether such windfalls foster corrupt practices (Morrison, 2012).

The consequences of natural disaster relief have been studied much less. The effect of such transfers on corruption may be less strong than that of resource revenues for at least four reasons. First, non-resource windfalls are typically one-time, unpredictable occurrences. As political elites have only a limited time in which to disburse the funds, the opportunities for corruption may be lower. In addition, non-resource windfalls such as disaster relief may be subject to stricter institutional rules and constraints (M. Bechtel \& Mannino, 2015). Thus, the possibilities for embezzlement for such resources may be fewer. Third, non-corrupt handling of disaster reconstruction may increase incumbents re-election chances. Finally, politicians may also not have enough time to build the infrastructure necessary to carry out corruption effectively, such as creating phantom firms to which embezzlement can be channeled. Therefore, if disaster funds are also prone to embezzlement, this would be an especially strong testimony to the appeal of corruption incentives.

\footnotetext{
${ }^{1}$ The latter is particularly likely when institutional constraints are strong (Monteiro \& Ferraz, 2010). Also, access to information may play a key role in reversing the negative link between windfalls and governance (Guiteras \& Mobarak, 2014). Coalition size may determine whether unearned income is used for societal benefit or to reward the leader and her cronies (Smith, 2008).
} 
In this paper, we examine how intra-governmental transfers affect local corruption in Bulgaria, shortly before the country's accession to the EU in 2007. We use a unique data set on the amount, use and abuse of disaster aid distributed to local governments by the central government following unexpected torrential rains which led to flooding in 2004 and 2005. The awarded funds represented a non-negligible financial injection (amounting to around $15.6 \%$ of municipal income for the average municipality). Local governments were the ultimate authority on how the money would be spent. What was not known at the time of disbursement was that an independent national auditing watchdog would be summoned in early 2006 to issue detailed reports on how the money was used. The resulting public reports chronicle a variety of infringements including: (1) contracts not awarded to the highest bidder or no bidding, (2) money channeled for the repair of buildings experiencing no damage, and (3) money given for no work.

We exploit the detailed information on embezzled resources to create an objective - as opposed to a perception-based - measure of corruption, which sums all the infringements recorded in a municipality between 2004 and $2005 .^{2}$ We recognize that only a working court system can unambiguously rule a particular practice to be corrupt. However, in the absence of an impartial judicial system in Bulgaria, we can rely on the detailed expert information provided by auditors. The transparency of our coding should facilitate further debate on how to construct objective corruption indices. ${ }^{3}$

We use the newly created corruption index to test an important hypothesis: do public fund transfers result in more corruption in local government? Our identification strategy exploits the quasi-random nature of the rainfall shock (conditional on several proxies for ground flood risk) to isolate exogenous variation in the amount of funds received by each municipality. According to our instrumental variable estimates, a $10 \%$ rise in per capita

\footnotetext{
${ }^{2}$ Objective corruption measures similar to ours may be more accurate than perception-based variables (B. A. Olken, 2009). See also Aidt (2003) and Rose-Ackerman (1999) for reviews of the corruption literature.

${ }^{3}$ Scholars can use our raw data to construct different measures.
} 
relief funds increased corruption by $9.8 \%$ in the average municipality, which is a sizeable effect. ${ }^{4}$ Although our research setup precludes panel analysis, we control for a wide range of additional municipal characteristics, such as economic and demographic variables, the political affiliation of the local government, mayor characteristics and ad-hoc fiscal transfers prior to 2004. We also discuss extensively threats to the exclusion restriction - including a direct effect of rainfall on corruption - and conclude that such scenarios are unlikely. We show that our results are robust to using an alternative, perception-based corruption measure from the Life in Transition Survey, a household and attitudes and values survey administered by the European Bank for Reconstruction and Development and the World Bank in Bulgaria in fall 2006, shortly after the data from the anti-corruption audits were made public.

Thus, we find that disaster windfalls are prone to embezzlement, even though they are less predictable and subject to stronger institutional controls. Our finding that money critical for infrastructure repair is systematically stolen means that those neediest of help are left without effective assistance. This can also slow down recovery for entire regions and damage the economy in a lasting manner. Private insurance is one possible policy option worth exploring in the future. In addition, our analysis implies that the attractiveness of the funds likely outweighs political benefits associated with the proper use of reconstruction relief. We find suggestive evidence that such funds are stolen in richer municipalities and in those with less informed voters, suggesting that mayors who believe they can get away with it misuse more. A final implication of our analysis is that different auditing institutions perform differently, partly because of different political control.

Our work complements a growing literature on the drivers of corruption in developing and transition countries, particularly using non-survey measures and arguably identified designs (Bertrand, Djankov, Hanna, \& Mullainathan, 2007; Ferraz \& Finan, 2011; Findley, Nielson,

\footnotetext{
${ }^{4}$ We show that this effect survives even if we control for the total funds received by each municipality, suggesting that we are not capturing a mechanical relationship.
} 
\& Sharman, in press; Fisman \& Miguel, 2007; Mironov \& Zhuravskaya, 2014; Reinikka \& Svensson, 2005). Our study is also related to work on the impact of natural disasters and unearned income on economic and political outcomes, such as M. M. Bechtel and Hainmueller (2011); Lazarev, Sobolev, Soboleva, and Sokolov (2014) and Quiroz Flores and Smith (2013). ${ }^{5}$

\section{Publicly provided disaster relief and corruption in- centives}

The debate on whether "unearned" income fosters corruption centers on the incentives of politicians to invest such income in public rather than private goods (Smith, 2008). The literature on foreign aid and the resource curse explores the degree to which such funds translate into more corruption and worse governance. Some scholars believe that foreign aid can be provided effectively (Milner, Nielson, \& Findley, 2016), either by bypassing local politicians (Dietrich, 2016) or by attaching effective conditionality to its provision (Bermeo, 2011). Others argue that the effectiveness of aid is conditional on institutions (Krasner \& Weinstein, 2014), and that its impact may be only temporary (Carnegie \& Marinov, 2016). Debate on oil rents seems to suggest that oil is not necessarily "free money" but that its usage depends on the prior existence of strong institutions. This begs the question of what can be done when such institutions are not in place to begin with, as is the case in countries like Bulgaria (Morrison, 2012).

In the discussion below, we situate the problem of public transfers in the wake of natural disasters in the broader debate on resource transfers as governance "curse" or "blessing". How the money will be spent will depend on political accountability, either induced by the ballot box or by an effective judicial system. Some of that context may be different in the case of disaster relief as compared to spending aid or resource endowments. Whether such

\footnotetext{
${ }^{5}$ See also Dell, Jones, and Olken (2014) for a review of this literature.
} 
transfers should be continued in the future, or dropped for alternative solutions, will also depend on whether the ability of local actors to embezzle tends to overpower the capacity to protect. Demonstrating the true impact of transfers on governance, given their non-random provision, is a challenge at the heart of the debate on whether government relief is desirable.

\subsection{The drivers of corruption in local government}

Consider a municipality which receives a financial windfall, such as flood relief from the central government. Municipalities may spend some or all of the allocated money for reconstruction. Local politicians who utilize aid effectively may be more likely to be re-elected in localities directly affected by the disaster as the population exhibits "voter gratitude" (M. M. Bechtel \& Hainmueller, 2011), while corrupt leaders may be punished at the polls (Klašnja, 2015). In addition, efficient handling of relief funds may serve as a signal of (local or national) government presence and competence even for voters in localities which may not have been directly affected by the disaster. ${ }^{6}$ Political parties may be able to build on the reputation of municipal politicians to win national elections, thus improving even further the re-election chances of local bureaucrats (Brollo \& Nannicini, 2012). This type of argument suggests that disaster relief should not result in higher corruption in local government.

Alternatively, local policymakers may also pocket some or all of the money for their own benefit, even if they care about subsequent re-election. First, patronage can be distributed to particular groups of voters who may be more likely to support incumbents at the polls, such as public sector workers (Monteiro \& Ferraz, 2010). Similarly, firms which obtain lucrative reconstruction contracts may "repay the favor" by financing a mayor's re-election campaign.

\footnotetext{
${ }^{6}$ Lazarev et al. (2014) find that such "demonstration effects" are responsible for unexpectedly high levels of government approval following wildfires in Russia in summer 2010. In Romania, Pop-Eleches and PopEleches (2012) show that even small amounts of targeted public spending (a 200 Euro voucher towards the purchase of a computer) make it more likely that recipients vote for the parties of the incumbent governing coalition. See also De La O (2013) and Manacorda, Miguel, and Vigorito (2011) for similar findings in Mexico and Uruguay, respectively.
} 
Second, local governments may misappropriate relief aid if they believe that the risk of being caught is low. For example, voters may not easily update their beliefs about politicians' competence when the media is weak (Ferraz \& Finan, 2008; Reinikka \& Svensson, 2005), or information acquisition and processing may reflect citizens' political preferences (Robertson, 2015). Likewise, less educated voters may find it more difficult to judge leaders' performance and to hold them accountable. As budget size increases, re-election probability may also increase as imperfectly informed voters may find it more difficult to detect theft and hold politicians accountable. ${ }^{7}$ Finally, incumbents may opt to steal funds now simply because doing so is more profitable than the uncertain payoff from a future election. Sizable and unexpected disaster relief may make corrupt activities particularly tempting as compared to waiting to grab other political rents later. Following this line of reasoning, one would expect flood assistance to result in corrupt behavior.

In short, the relationship between corruption and re-election is a priori ambiguous. We could link some of these observations to data, and seek to establish the causal mechanisms via which transfers impact corruption. One implication is that highly corrupt mayors anticipate punishment and take themselves out of the re-election race. Moreover, such an effect is likely to be stronger among incumbents who were elected with smaller margins in the previous election. This is a potentially testable mechanism linking greater appropriation of disaster-relief funds to different types of local politicians. More generally, it is of interest to establish whether incumbents are punished at the polls when they misbehave, and under what circumstances such penalties are stronger. ${ }^{8}$

Whether politicians decide to steal should also depend at least in part on the likelihood of audits, and their anticipated consequences. In a seminal article, B. Olken (2007) compared

\footnotetext{
${ }^{7}$ In addition, a larger budget may affect corruption indirectly, by inducing a decline in the average ability of the pool of individuals entering politics. Incumbents may be re-elected, despite also engaging in more corruption (Brollo et al., 2013).

${ }^{8}$ It could also be that a large portion of the electorate may simply be "irrational" and punish politicians for essentially random events, such as shark attacks or floods (Achen \& Bartels, 2004).
} 
the efficiency of two methods of reducing corruption: increasing audits by government officials and increasing grassroots participation. The results show that audits work but find no effect of the latter mechanism. Infrastructure reconstruction following a natural disaster is similar to the provision of public goods investigated by Olken.

In the context we study, two auditing agencies conducted their investigations into how the money had been spent. What is interesting from our point of view is that the auditing watchdogs had different types of political control and professionalization. Thus, we try to learn whether political control of auditors matters, and to what degree. In addition, local politicians did not anticipate that the audit would be so far reaching and widely publicized. It is likely that a credible and omni-present threat of audits would have reduced public fund misuse to a greater extent.

Credibly identifying the dynamics of corrupt practices following disaster relief transfers is important for both academics and policy makers. People and local governments are especially vulnerable following natural disasters. If we observe that intra-governmental transfers affect local corruption, even without data to measure the overall change in welfare in flooded municipalities, it is more likely than not that flooded municipalities experienced less reconstruction spending than would be optimal (Litschig \& Morrison, 2013). Anecdotal evidence points in this direction. This means that important opportunities to deal with the negative consequences of disasters are lost.

As Kosec and Mo (2015) argue, using evidence from Pakistan, helping local communities after natural disasters is also important for the future economic aspirations of the local population. Without effective help, agents may start under-investing in economically productive activities, which would sap economic growth. As Duru (2016) suggests, private insurance is possible, whether purchased by individuals or sub-national governments, and it may be a preferable solution to the commitment problem involved in not offering central transfers after a disaster. 
In the end, the question is whether a country's institutions are strong enough to allocate efficiently a potentially massive transfer of public funds following a natural disaster. On the one hand, Bulgaria's transition to a market economy has been difficult, with institutional building lagging behind and a relatively weak legal system. On the other hand, accession negotiations to join the EU had forced local and national politicians to accept many specific reforms, including transparent procedures for allocating public funds that were intended to guarantee the tax payer's interest. If our results demonstrate that even in this setting, transfers increase corruption, the implication would be that further redistribution at the local level of national and EU money needs to be done carefully, pending extensive reform of the justice system.

Moving the debate forward depends on identifying the effect of disaster relief transfers on reconstruction efforts. Our findings on this would pertain most directly to the question of how to deal with such disasters in the first place. This is an important area and question in its own right. Due to the links to other types of unearned income, there may be implications for the study of corruption more generally. We revisit some of those tentative links in the concluding section.

\subsection{Hypothesis}

We build and exploit a novel objective measure of corruption, in order to test the following hypothesis:

Hypothesis 1. Municipalities which received more flood-related transfers experienced more corruption. 


\subsection{Research Design}

Credibly identifying the impact of relief funds on local government corruption raises two challenges: (1) constructing a reliable corruption measure; and (2) isolating exogenous variation in disaster aid. To deal with the first point, we exploit the fact that in early 2006 the central government commissioned an independent audit agency (the Bulgarian National Audit Agency) to conduct comprehensive inspections on how the funds had been used by each municipality. We build an index of corruption using information on the various spending infringements recorded by the agency in each municipality.

The main difficulty in solving the second identification issue lies in the fact that unobservable characteristics may drive both the amount of disaster aid which the municipality receives and subsequent corruption. For example, charismatic mayors may be more likely to be awarded a higher amount of funds as well as to commit and get away with spending violations. A "naive" regression exploring the link between disaster aid and corruption may also suffer from reverse causality: more corrupt politicians may be able to extract a higher amount of assistance from central government.

Previous work has addressed the latter concern by using regression discontinuity designs. In Brazil, intra-governmental transfers change discontinuously and exogenously at given population thresholds, with all municipalities in the same state and the same population bracket receiving the same transfers (Brollo et al., 2013). Other scholars have claimed that oil-induced fiscal windfalls in Brazil are exogenous conditional on observable municipal characteristics and geographical rules for royalty distribution (Caselli \& Michaels, 2013; Monteiro \& Ferraz, 2010). ${ }^{9}$ However, rule-based allocations of local transfers are rare in practice.

We utilize a new instrument for disaster-related assistance, derived from the case of Bulgaria during the 2004-2005 floods. The central government intended to allocate more money

\footnotetext{
${ }^{9}$ See also Vicente (2010) for the case of Sao Tome and Principe.
} 
to localities which experienced more flooding. ${ }^{10}$ We exploit this information to construct a novel instrument for flood aid: the monthly rainfall deviations (relative to a historical average) in each municipality over the period 2004-2005. We argue that, conditional on controls for ground flood risk and other municipal characteristics, the instrument captures exogenous variation in the amount of flood aid received by each municipality. We describe in more details our data and IV strategy in the next two sections. Due to the richness and granularity of our data, we are also in a position to suggest some plausible mechanisms driving the hypothesized relationship, which we discuss in more detail in Section 7.

\section{Background}

\section{$3.1 \quad$ Floods}

Between June 2004 and December 2005, Bulgaria was unexpectedly hit by several waves of torrential rain which caused extensive flooding, with an estimated cost exceeding 500 million Euros. ${ }^{11}$ Just in August 2005 alone, nearly one billion liters of water fell over a total area of 6,000 square kilometers, while the capacity of existing dams was only 250 million square meters. According to hydrologists, such extreme rainfall is very rare, as the probability of its occurrence is between $1 / 1000$ and $1 / 10,000 .{ }^{12}$ The scale of the destruction was unexpected.

To deal with the destruction following the floods, the central government awarded nearly 67 million Euros to 257 flood-stricken municipalities. ${ }^{13}$ Each municipality had to apply for financing following a well-defined procedure and specifying the particular projects, usually related to rebuilding roads, bridges or buildings, for which the awarded funds would be used.

\footnotetext{
${ }^{10}$ The central government did not follow cut-off rules for distributing the funds (for instance, related to the number of destroyed buildings).

${ }^{11}$ Newspaper Trud, May 29, 2005.

${ }^{12}$ See Bulgarian National Television Website, http://infocenter.bnt.bg/content/view/full/679.

${ }^{13}$ Mediapool.bg at http://www.mediapool.bg/firmi-na-dps-usvoyavali-zle-parite-za-ukrepvane-sled-stariteporoi-news115354.html. 1 Euro is equivalent to around 2 BGN (Bulgaria's currency).
} 
Although relatively small in absolute terms, these disbursements presented a substantial financial injection for many of Bulgaria's impoverished local governments. The average municipality received slightly over 250,000 Euros, which amounted to approximately 15.6\% of its 2000 income and $21 \%$ of its annual budget (using data from 2004 and 2005). ${ }^{14}$ The poor handling of the disaster by the central government led to much discussion in Parliament and in the media, which prompted a subsequent investigation and audits. ${ }^{15}$

\subsection{Audits}

Part of the richness of our study is that we can contrast the corruption reports of two agencies, one expert-based and one partisan. Thus, we can speak not only to the issue of transfers and corruption, but also offer some insights into institutional design. Experts are more reliable and less biased, which is perhaps intuitive but cannot always be shown as immediately as in the case we describe. What we find is that the two agencies reached radically different conclusions about the scale of corruption in affected municipalities, reflected in the very low correlations between the two data sources. While it is true that even a politically independent agency may not be able (or willing) to record the "true" amount of bribery, institutional design is still important for detecting corrupt activities.

The central government ordered detailed audits of all municipalities which received floodrelated funds in late February-early March 2006. Two different government agencies were summoned. The Bulgarian National Audit Agency (BNAA) audits entities financed by the national budget and alerts other agencies (including Parliament or a court) in the instances of suspected criminal activity. The agency is non-partisan, and several pieces of evidence

\footnotetext{
${ }^{14}$ Nearly 150 million Euros (including 15.2 million Euros from the EU) were also disbursed in 2006. Since, as we discuss below, a fund use audit was ordered by the central government in February-March 2006, we only focus on funds given in 2004 and 2005.

${ }^{15}$ In the online Appendix, we discuss more extensively the political parties comprising the government coalition which was in power at the time, as well as who controlled key ministries responsible for distributing the flood related funds. While we were unable to obtain copies of the actual applications, rainfall variation is still an exogenous shock to the amount each municipality received.
} 
suggest that this is true not only on paper but also in practice.

First, BNAA has complete control over its budget which cannot be changed by Parliament. Second, although its senior management (consisting of a director and ten board members) is elected by Parliament, their terms are for nine years, as compared to the fouryear election cycle. ${ }^{16}$ Third, BNAA must follow international financial audit criteria, such as those developed by the International Organization of Supreme Audit Institutions (INTOSAI) and the European Court of Auditors (ECA). During the period studied in this paper, the EU subjected BNAA to particularly close scrutiny over the compliance with these standards due to Bulgaria's accession in 2007.

Even so, one may still be concerned that Parliament's involvement in the selection of BNAA's leadership may compromise its independence. A recent report by Transparency International suggests that it is difficult for state institutions to exercise control over the agency's activities. ${ }^{17}$ Moreover, the long tenures of BNAA's directors make it less likely that it caters to narrow political interests. BNAA's independence is also strengthened by its high transparency, as information from its audits and internal documents is readily available on its website and in the media.

BNAA audits are conducted by highly competent teams of auditors who must pass a public examination and earn very competitive salaries. Supplementary paid employment (with the exception of research activities at a university) is prohibited. BNAA staff involved in a financial inspection have access to all of the auditee's documents and can request additional data and written or oral explanations. Once an audit is completed, auditors produce a report and recommendations for action, which are shared with the Ministry of Finance

\footnotetext{
${ }^{16}$ Elections for a new management board can take place no less than three months before the incumbents' terms expire. None of the BNAA managers may have been involved in government or local administration positions in the last three years. In 2014, several years after the events on which this paper focuses, the Movement for Rights and Freedoms (one of the most corrupt parties and a central player in fund misuse) attempted with some success to take away BNAA's independence, further confirming the agency's bite. See http://www.capital.bg/politika_i_ikonomika/bulgaria/2014/12/12/2437201_smetna_palata_30/.

${ }^{17}$ http://nis.transparency.bg/pdf/pillars/8.\%20national\%20audit\%20office.pdf.
} 
and Parliament. BNAA then follows up on the execution of these recommendations, and if the actions undertaken by the audited entity are unsatisfactory, it alerts other government agencies. $^{18}$

The Public Financial Inspection Agency (PFIA), by contrast, can either conduct selfinitiated audits of public entities, or act upon external recommendations (by BNAA or a court, for instance). The crucial difference between PFIA and BNAA is that the former can directly impose legally binding penalties. At the same time, experts agree that BNAA is very active when it comes to detecting misbehavior and alerting the appropriate agency. BNAA's professional ethos is to establish the deviations it sees between the legislative framework and actual spending, in order to give the legislature an adequate picture of the situation on the ground. Its credibility rests on professionalization and not directly on the inability to penalize. BNAA's reports are discussed extensively in the media and policy circles. In addition to holding responsibility for detecting irregularities in the spending of EU funds, the agency recently expanded its audits to political parties and to commercial companies in energy and pharmaceuticals, among others. This suggests that information from the BNAA audit reports is not simply "cheap talk" and should capture meaningful variation in corruption across municipalities.

The major problem with interpreting the data from the PFIA audits is that the agency is politically affiliated, as it is part of the Ministry of Finance. Its director is appointed by the Finance Minister for a four-year term, and while PFIA employees must have university-level training in economics, they are not required to pass an examination. The head of PFIA at the time was a political appointee of the Movements for Rights and Freedoms (MRF) party, a symbol of corruption, especially as far as local government spending is concerned. ${ }^{19}$ In

\footnotetext{
${ }^{18}$ See http://www.bulnao.government.bg/bg/articles/zakon-za-smetnata-palata-876 and http://www.bulnao.government.bg/bg/articles/istorija-897. Unfortunately, data on the number and type of issued recommendations are not available in our data set.

${ }^{19}$ http://www.dnes.bg/politika/2013/06/05/ginka-draganinska-poema-shefstvoto-na-adfi.190013
} 
fact, PFIA recorded spending violations in less than a third of the municipalities in which BNAA detected corruption, and the correlation between the two corruption measures is less than 0.10. In addition, we find that PFIA is nearly five times more likely to under-report corruption in those municipalities in which either the majority of the council, or both council and mayor, were affiliated with the party that appointed the head of PFIA. ${ }^{20}$ As a result, in the regressions below we focus mostly on the BNAA corruption index. We present results with the PFIA data, which are similar but very imprecisely estimated, when conducting robustness checks.

Both agencies started their audits in late February-March 2006 and finished them in early September 2006. PFIA covered all 257 municipalities which received flood-related assistance, while BNAA audited only those municipalities where the amount of funds was particularly large (227 in total). The availability of data from two different agencies adds to the richness of our study, as we are able to show how political independence impacts reporting content. In the next section, we demonstrate that municipalities which were audited by BNAA are very similar to those which were not audited along a variety of observable characteristics (including municipal political affiliation), suggesting that selection is unlikely to drive our results.

\section{Data}

For each municipality, BNAA provides information on the amount of flood-related assistance, along with a description of the activities for which the funds were used. In the regressions below, we sum these amounts over 2004 and 2005 and divide them by the population of each municipality (we take the logarithm of the final quantity). Figure A1 shows the geographical distribution of per capita funds in the country.

\footnotetext{
${ }^{20}$ See Table A10.
} 
For each of the audited municipalities, BNAA recorded all infringements related to the use of flood aid received during the period January 1, 2004 - December 31, 2005. BNAA groups infringements into four broad categories: (1) public procurement (for example, no public procurement procedure was used by the municipality to select firms); (2) use of funds (for instance, there was payment for activities not listed in the contract); (3) reporting (for instance, no reports on fund use were sent to the Ministry of Finance); and (4) accounting and control (for instance, inaccurate accounting recording of the contracts). We provide more details on these categories and sub-categories in the online Appendix. Our corruption index sums all the recorded infractions for each municipality. ${ }^{21}$ Figures A2 and A3 summarize the geographical distribution of infringements recorded by BNAA and PFIA, respectively (areas in striped font indicate that no audit was performed in that particular municipality).

For instance, in Belovo municipality in Southern Bulgaria, a major bridge connecting the two parts of the town (located on either side of a large river) was destroyed in Spring 2005. On August 16, 2005, the municipality paid 200,000 Euros to local firms to fix the damage, and the mayor signed off the complete work. As the later report shows, the work had not been done and the bridge was still not functional in summer 2006. In another example, 27,000 Euros were paid by the municipality for building an existing 12 kilometer road. ${ }^{22}$ Our dataset records multiple instances of such corrupt activities.

One issue with our approach could be that the constructed corruption index may capture a mixture of corruption and mismanagement. If our dependent variable is a proxy for the latter, our results could simply indicate that municipalities which receive more flood assistance do not have the administrative capacity to deal with the increased reporting burden.

While our measure includes items that have been associated with corruption in the rest

\footnotetext{
${ }^{21}$ Unfortunately, we have no information on the amount of funds associated with each violation.

${ }^{22}$ Newspaper Sega at http://www. segabg.com/article.php?id=273924.
} 
of the literature ${ }^{23}$ it also contains infringements related to mis-reporting and mis-classifying the disaster aid. At first glance, the latter type of infractions may seem benign. However, an examination of official documents outlining the BNAA audit criteria speaks to the contrary. BNAA follows specific rules designed the EU and the International Standards of Supreme Audit Institutions (adopted by the Bulgarian Parliament in 2000) on what constitutes public fund fraud. For example, although incomplete accounting procedures may be due to misinformation and neglect, the audit guidelines explain that such omissions are usually deliberate and are therefore strong signals of fraud or corruption. Auditors are provided detailed examples (including from real-life situations) of when accounting mis-reporting indicates corruption, and instructed to investigate further if the errors are purely accidental or in fact committed purposefully. ${ }^{24}$ Accounting oversights which are likely to be associated with fund fraud are then recorded against each audit criterion in the report, while purely administrative infringements are described in a separate section. Importantly, we have excluded the latter as part of our dependent variable.

The audit reports provide further evidence that all infringements documented by BNAA are important indicators of fraud. For example, in Elhovo municipality, BGN 136,675 (approximately 68,000 Euros) from the funds earmarked for post-flood reconstruction were withdrawn in December 2005 even though the repair works were not completed. In the municipality's accounts, however, this sum was not recorded as "withdrawn," providing strong evidence that the money was misappropriated. In Straldja municipality, the files reporting on how the funds were used which the municipality was required to send to the Ministry of Finance were incomplete. In particular, no firm contract was supplied and there were no pictures showing the condition of the repaired objects once the works were completed..$^{25}$

\footnotetext{
${ }^{23}$ As in Ferraz and Finan $(2008,2011)$, our data set covers infringements related to fraud in the procurement of goods and services; diversion of funds; overinvoicing; incomplete public works (paid but in reality not finished); or (possibly) the use of fake receipts and phantom firms.

${ }^{24}$ See www. bulnao.government.bg/files/_bg/œ_1240.doc for the full report.

${ }^{25}$ Both pieces of evidence come from the municipality reports issued by BNAA on which our corruption
} 
Once again, the auditors' check showed that since these omissions were deliberate, they were most likely due to corrupt activities. In Vetovo municipality, BGN 146,943 were signed off on and paid for by the municipality for work that was never done. ${ }^{26}$ We are therefore fairly confident that we are successfully able to distinguish mismanagement from corruption.

It is also reassuring that our results survive when we calculate the corruption index using principal component analysis (in the robustness checks), suggesting that our findings are not driven by the idiosyncrasies of a particular coding approach. We also provide our raw data in its entirety, ${ }^{27}$ with as much of it as possibly clearly labelled in English, for the benefit of future research on the topic.

We should point out that only a working judicial system (not present in Bulgaria) can definitely pronounce a particular activity to be corruption. We recognize that even our best measure, absent that, may not fully track corruption. Our index reflects what was widely discussed in the media as corruption, and, as we show later, matches perception-based indices of corruption to a high-degree. Thus, while each agency may have some biases, we believe that an increase in our measure is correlated with increases in corruption, which is what we need for our basic results to hold.

\subsection{Flood damage and risk}

We obtain monthly rainfall data for 2004-2005 from the Bulgarian National Institute for Meteorology and Hydrology. Since the number of municipalities is greater than that of weather stations (101), we adopt an interpolation procedure using a radius of $45 \mathrm{~km}$ and weights which are the inverse of the municipality's distance to a station. To make sure that our rainfall data do not simply capture long-term precipitation patterns, we calculate the coding is based. The Elhovo report was issued on 27.03.2006, while the Straldja report was issued on 02.03.2006.

${ }^{26}$ See www. bulnao government.bg/files/_bg/Otchet-2005-final2.doc.

${ }^{27}$ See the online Appendix. 
rainfall variable used in the regressions as the monthly rainfall percent change relative to a monthly historical average. The latter is based on precipitation data for the period 19311985 from Koleva and Peneva (1990) interpolated using the same procedure. For example, the rainfall quantity for January is simply $\frac{\text { Rainfall }_{\text {january, } 2004}-\text { Rainfall }_{\text {january }, 1931-1985}}{\text { Rainfall }_{\text {january }, 1931-1985}}$. For each municipality, we then take the average rainfall value for all months in 2004 and 2005 for which the change relative to the historical value was at least $30 \%$. Ideally, we would have preferred to look at daily rainfall deviations, but such detailed data are unavailable. We developed the measure used in this paper in close consultation with Dr. Ivan Penkov, head of the Climatology, Hydrology and Geomorphology department at Sofia University, who has conducted extensive research on torrential rains and the water sector in Bulgaria. Our approach is also very similar to that of other studies in this literature, such as Miguel, Satyanath, and Sergenti (2004).

To give a better sense of this measure, Figure 1 plots it graphically for each month and municipality, with the red horizontal line indicating our 30\% cut-off value. The figure shows that the summer months of 2004 and 2005, along with February 2004, were periods of particularly heavy rainfall for many municipalities. We experiment with alternative cut-off values (10\%-50\%, in the robustness checks and in unreported results) and obtain very similar results.

[Figure 1 around here]

We include three proxies for ground flood risk. First, we control for the number of settlements that are located within 1 kilometer of a water body (dam, lake or river), since households located close to water are more likely to experience flooding when there is extreme rainfall. Second, we control for average municipal elevation and slope, as flooding may be more intense in municipalities located at a higher altitude and with a sloping terrain. We also include controls for latitude and longitude. It is important to note that only rainfall 
deviation is exogenous. Flood risk measures that code proximity to water body and so on are not appropriate as instruments because they may be correlated, via unobservables, with corruption. Our estimation strategy, described in more detail below, reflects that.

\subsection{Additional variables}

In various specifications, we include controls for four categories of municipal characteristics: (1) economic conditions (log municipal income per capita, unemployment and net privatization income); (2) media and civil society (local newspaper circulation per capita, share of population with university degree, share of urban population and voter turnout in the 2003 local elections); (3) whether the mayor and council belong to the ruling coalition, and whether the mayor and council belong to the party holding the disaster funds portfolio. ${ }^{28}$ In the robustness tables, we also include two mayor characteristics, margin of victory in the 2003 elections and a dummy for whether the mayor had any political experience before 2003. ${ }^{29}$ In addition, in the robustness checks we also control for the per-capita amount of additional ad-hoc funding received by each municipal government from the central government (in 2003; intended to cover budget deficits for "state affairs."). This variable may indicate prior incidence of politically motivated intra-governmental transfers. All of these data cover years prior to 2004, and the online Appendix provides detailed information on exact definitions and measurement.

\footnotetext{
${ }^{28}$ The Movement for Rights and Freedoms (MRF), or DPS in Bulgarian, a party whose electorate comprises mainly Bulgarian Turks, controlled the ministries allocating the flood aid. See the online Appendix for more details.

${ }^{29}$ See Brollo et al. (2013) for a discussion on the effect of economic variables on corruption. Ferraz and Finan (2008) and Reinikka and Svensson (2005) provide evidence that bribery flourishes in places with weaker media. Brollo and Nannicini (2012) link political affiliation, politician characteristics and the degree of election closeness to corruption incentives.
} 


\subsection{Selection and summary statistics}

Although the BNAA audit covered most municipalities (227 out of 257) and $96.8 \%$ of disbursed funds, one concern could be that auditors selected municipalities non-randomly. In Table A1, we compare audited and non-audited municipalities across a variety of observable characteristics. The major difference between the two groups of municipalities is that localities which received more funds were more likely to be audited. On average, audited municipalities received assistance amounting to BGN 43.3 (around 20 Euros) per capita, while for non-audited ones the figure is around BGN 10 (around 5 Euros). This is not surprising, since official BNAA documents point out that the agency chose to audit those municipalities in which the amount of disbursed funds was particularly high.

Few additional characteristics are associated with the probability of audit. Apart from geographic characteristics (such as elevation and relief slope) which may be associated with flooding, audited municipalities have less unemployment. The average municipality received BGN 513,285 (around 250,000 Euros), which amounted to $15.6 \%$ of municipal income and $21 \%$ of its average annual budget in 2004-2005. Corruption infringements were recorded in $105(47.1 \%)$ of audited municipalities, and the average corrupt municipality committed 1.7 violations (see also Figure A4 for a histogram of the corruption index). Both groups of municipalities have municipal income per capita around BGN 240 (120 Euros). Importantly, the table also shows that the audit choice was not driven by political considerations. ${ }^{30}$

Were the municipality rainfall shocks really exogenous? We try to rule out the endogeneity of rainfall in Table A2 which regresses our rainfall measure (which, as described above, uses data from 2004 and 2005) on all the independent variables used in the subsequent regressions (measured in 2003 or earlier), along with a dummy for whether the municipality was audited or not. Apart from a few geographical variables, none of the demographic, economic

\footnotetext{
${ }^{30}$ If anything, municipalities with mayors and/or councils affiliated with MRF were more likely to be audited.
} 
and political variables predict the incidence of rainfall at the municipal level. This balancing test makes us more confident that our analysis is picking up a true effect of funds (via rainfall) on corruption, rather than simply a spurious correlation due to omitted variables.

\section{$5 \quad$ Estimation strategy}

Our estimation strategy exploits the unexpected nature of the natural disaster to isolate exogenous variation in the amount of flood aid received by each municipality. To identify the impact of flood-related assistance on local government corruption, we estimate an instrumental variables regression, where the second stage is given by:

$$
\text { CorruptionIndex }_{i r}=\alpha_{i r}+\beta_{1} \text { Logfunds }_{i r}+\beta_{2} \text { FloodRisk }_{i r}+\boldsymbol{X}_{\boldsymbol{i r}} \beta_{3}+\gamma_{r}+\epsilon_{i r} \text {. }
$$

For each municipality $i$ in region $r$, CorruptionIndex $x_{i r}$ is calculated by summing the spending infringements identified by BNAA during 2004-2005, Log funds $s_{\text {ir }}$ is the total floodrelated assistance received by the municipality (in logs and per capita) during 2004-2005, and FloodRisk $_{i r}$ is proxied by the number of settlements within $1 \mathrm{~km}$ of a water body, average elevation and slope. $\boldsymbol{X}_{\boldsymbol{i r}}$ is a matrix of municipality-level characteristics that vary across specifications and include the following broad categories described above: (1) geography; (2) economic conditions (measured prior to 2004); (3) media and civil society (measured prior to 2004); (4) composition of local government since the 2003 local elections; and (5) mayor characteristics (in the robustness checks only). As a proxy for auditor effort, we also control for each municipality's distance to the closest BNAA territorial division, since auditors may audit less thoroughly municipalities which are located further from the agency's regional center. ${ }^{31}$ Regional dummies (at the NUTS-2 level) and robust standard errors are

\footnotetext{
${ }^{31}$ BNAA has six regional divisions, located in Burgas, Varna, Plovdiv, Vidin, Ruse and Sofia.
} 
also included. Unreported results are robust to using clustered standard errors at the oblast level (Bulgaria has 28 oblast).

We instrument $\operatorname{Logfunds}_{\text {ir }}$ as follows. For each municipality, we calculate the average monthly rainfall change (relative to a historical average) for all months in 2004 and 2005 for which it exceeded the historical average by least 30\%, as explained above. The corresponding first stage is:

$$
\text { Logfunds }_{i r}=\alpha_{i r}^{F}+\beta_{1}^{F} \text { Rainfall }_{i r}+\beta_{2}^{F} \text { FloodRisk }_{i r}+\boldsymbol{X}_{\boldsymbol{i r}} \beta_{3}^{F}+\gamma_{r}+\epsilon_{i r}^{F}
$$

We do not include our proxies for flood risk as additional instruments, as the exclusion restriction is unlikely to be satisfied. In contrast to our rainfall instrument which captures short-term climatic fluctuations, fixed characteristics such as distance to water or elevation may also proxy for long-term factors which may directly affect municipal corruption.

\section{Results}

\subsection{Main results}

Table 1 presents results from running several variants of our estimating equation. In columns (1) and (2), we present "naive" OLS specifications. Column (1) includes controls for geogra-

phy, economic conditions, and media and civil society, while column (2) also accounts for the political composition of local government. Although these estimations cannot be interpreted as causal, they serve as a useful benchmark for our IV regressions. The coefficient estimate in column (2) (0.261) suggests that a 10\% increase in flood-related assistance (per capita) is associated with a 0.025 -unit increase in the corruption index, which is around $3.2 \%$ relative to its mean $(0.775)$.

The next three columns show estimates from our IV specifications. All in all, the results 
provide evidence in favor of Hypothesis 1. Columns (3) and (4) are the IV equivalents of column (1) and (2), respectively. The coefficients on funds per capita are positive and around three times higher compared to the OLS estimates, suggesting that omitted variables bias the coefficient on funds received downward in the latter specification. This could also be due to reverse causality in the OLS estimates: it is possible that the central government opted to give historically more corrupt municipalities less funding, knowing that a large portion of the aid would be stolen. Similarly, municipalities with more competent and honest leaders may have received more funding and experienced less corruption, which would again attenuate the OLS coefficient on funds received. The first-stage regressions are precisely estimated, with an F-statistic exceeding the Stock-Yogo critical value of 16.38 (Figure A5 presents the first-stage relationship graphically). Crucially, the coefficient on funds per capita changes very little when we also account for whether the municipality's mayor and/or council belong to the ruling coalition (column (4)). The coefficients on the political affiliation variables (shown in Table 2) are insignificant, suggesting that the quality of BNAA's audits did not depend on the political sympathies of the municipality. ${ }^{32}$ The point estimate in column (4) implies that a $10 \%$ increase in funds per capita leads to a increase in the corruption index of 0.08 points, or $9.8 \%$ relative to the sample mean, which is a strong effect.

In column (5) we relax the linearity assumption on which our previous regressions are based and run an IV-Poisson specification, which is appropriate since the corruption index takes a value of 0 for approximately half of the municipalities in our sample. The coefficient estimate on funds received (shown as a marginal effect) is slightly smaller than that obtained in column (4), though it remains strongly significant.

\section{[Table 1 around here]}

In Table 2 we present results from our first-stage regressions. The table shows that our

\footnotetext{
${ }^{32}$ Results are unchanged if we instead look at whether the municipality is controlled by an opposition party (the latter intended to proxy for swing municipalities).
} 
rainfall measure is a strong predictor of the amount of disbursed flood assistance. From the geographical variables, distance to BNAA regional center is the only significant variable, though in unreported results settlements near water and relief slope become positive and significant once the former variable is excluded.

[Table 2 around here]

\subsection{Validity of the IV approach}

The adopted IV strategy would be valid provided that three conditions are satisfied. First, the first-stage relationship between Rainfall and Logfunds must be strong. Second, the instrument should not be correlated with the error term in the second-stage regression. Third, rainfall should not affect corruption directly.

Our regressions above indicate that rainfall indeed explains a significant portion of the variation in funds received, with F statistics comfortably exceeding the Stock-Yogo cut-off of 16.38. Moreover, concerns about omitted unobservable characteristics are less salient, since our estimations include a wide range of municipal controls (including the three different proxies of flood risk) and mayor characteristics, along with regional dummies. In addition, as we showed in Table A2, municipal demographic, economic and political variables are uncorrelated with the rainfall shock, suggesting that our instrument is not simply a proxy for unobservables. ${ }^{33}$ Moreover, by construction, our instrumental variable parses out any historical rainfall effects and exploits essentially random precipitation fluctuations within a narrow two-year period. This particular characteristic of our IV also makes a direct effect of rainfall on corruption less likely.

Even so, one may be concerned about a direct link between rainfall and embezzlement if, for instance, flooding created organizational chaos which made it easier for politicians

\footnotetext{
${ }^{33}$ Foreign assistance was limited in size and was processed through the central government, rather than received directly by municipalities. In addition, there were no conflicts (ethnic or others) linked to the natural disaster which could explain the observed patterns.
} 
to sidestep official regulations and engage in corrupt activities. This scenario could have produced corruption even in the absence of cash transfers. However, the existing evidence weakens such a hypothesis. Affected municipalities had to follow strict regulations for applying for funds, ${ }^{34}$ and all requests had to be approved by the oblast governor. Specific instructions were issued that it was not acceptable for municipalities to hand out money to affected families or firms without following the accepted procedures. As the head of the Ministry of Disasters explained, "It looks like in some municipalities mayors are trying to take advantage of the situation... meaning that when an emergency is declared they can ask for more money. I warn you that the Ministry is very thorough in reviewing all requests for funds and we send a commission of assessors to the affected places to verify the damage..." 35 Although it is possible that the natural disaster may have made it easier for local politicians to appropriate existing resources, something which we unfortunately cannot observe, the increased oversight by the central government and by the EU makes this less likely. In addition, there is little evidence that the natural disaster encouraged corruption by reducing the effectiveness of enforcement, which was already poor prior to the disaster. ${ }^{36}$ If anything, higher scrutiny may have increased the likelihood of punishment of corrupt politicians.

A related critique could be that heavier rains may make monitoring of reconstruction projects harder, leading to higher corruption, even in the absence of increased funds. This is less convincing for at least two reasons. First, most of the flooding episodes were isolated and happened in 2004 and 2005, or at least four months before the BNAA audit started. This means that localities had sufficient time and ability to observe reconstruction. Second, by law each municipality is required to oversee re-building works and send detailed reports (along with photographic material) to the Ministry of Disasters, something which was also

\footnotetext{
${ }^{34}$ Initially, 11 documents were required; in August 2005 the government reduced this number to 4.

${ }^{35}$ Mediapool.bg at http://www.mediapool.bg/kmetovete-obvineni-che-se-vazpolzvat-ot -navodneniyata-news115295.html.

${ }^{36}$ See the 2006 report "On the Eve of EU Accession: Anti-Corruption Reforms in Bulgaria" mentioned earlier.
} 
verified by BNAA auditors. Since this process is coordinated locally, monitoring should be relatively straightforward and should not depend on the length or scale of the reconstruction.

Finally, it is possible that more corrupt municipalities also had poorer drainage systems, which could have led to more flood damage and more fiscal transfers to deal with the disaster. As we explained in section 7 below, the management of water resources and sewage had been universally poor since the early 1980s due to lack of funds. In addition, the quality of drainage facilities is likely to be correlated with other municipal characteristics for which we control, such as municipal income per capita, unemployment and level of urbanity.

\section{Discussion: Robustness and Suggestive Mechanisms}

\subsection{Identification threats}

Did local governments adjust their behavior in expectation of the audits? Four pieces of evidence suggest that the inspections were largely unforeseen. Although municipal audits were performed by both BNAA and PFIA prior to 2006, they were mostly ad-hoc and never covered a large number of municipalities. Moreover, official communication between the government and the two agencies characterizes the audits as "emergency checks." 37 In addition, the law stipulates that BNAA's work must be based on an annual plan, in which the government can only request a maximum of five additional audits, unless there are exceptional events to consider. Finally, as discussed above, newspaper publications indicate that the central government ordered the municipal audits following extensive pressure from the opposition parties and the media.

Another possibility is that our results may be driven by political biases in the auditing process. For example, swing municipalities (those not affiliated with the central government

\footnotetext{
${ }^{37}$ This information is from records of a meeting of the Government Commission for Fighting Corruption conducted on February 2, 2006, shortly before the audits were announced in late February-March 2006.
} 
coalition) may be more likely to receive disaster aid and to be exposed as corrupt. This is less of a concern not only because our instrument captures only exogenous variation in the amount of received funds, but also because our results do not change once we include municipal political controls in the regressions. BNAA's non-partisanship, which we discussed extensively above, also speaks against this scenario.

Even if BNAA's audits were not politically motivated, a third critique could be that, due to pressure from the media and Parliament, the agency simply audited more intensely municipalities which received more funds. However, our regressions use per-capita flood assistance and control for each municipality's distance to the closest BNAA territorial division (since inspections in municipalities located further from the agency's regional center may have been less thorough). Controlling additionally for total flood assistance (reported in Table A6) makes no difference to the results. Furthermore, BNAA guidelines (issued for the specific audits which we examine) specify explicitly that all auditors must follow the same criteria in all municipalities. Although auditors were not assigned randomly, they were rotated across municipalities, further alleviating concerns that some municipalities were more scrutinized than others. ${ }^{38}$

A fourth possibility is that historically corrupt municipalities may have been less ready for the floods, since funds earmarked for flood prevention or levee building may have been more likely to be stolen. Under this scenario, such localities could have received more disaster aid and would have experienced more flood-related corruption. This is less likely to be the case for three reasons. First, all of our regressions include different measures of ground flood risk (number of settlements within one kilometer of a water body, slope and elevation), along with a wide range of municipal geographic, economic and political characteristics which may also affect flood readiness. Second, the management of water resources deteriorated throughout

\footnotetext{
${ }^{38}$ As we discussed above, the audits were nearly universal and covered more than $80 \%$ of municipalities and $96.8 \%$ of funds disbursed. Note that even if the audits were indeed random (as in Ferraz and Finan $(2008,2011)$ ) ruling out completely the issue of varying and unobservable auditor effort is still challenging.
} 
the country since the early 1980s, with riverbed cleaning and the upkeep of levees and other protective equipment neglected due to lack of funds. ${ }^{39}$ Third, monitoring and containing weather risk has been uniformly poor. Even today, no system of early warning exists, and rainfall measuring apparatus, which would have provided detailed information to generate early flood warnings, still lack in most dams.

A final concern relates to the possibly endogenous location of weather stations in our data set. In Table A3 we compare municipalities in which there is at least one weather station with those where we need to interpolate rainfall. On average, both groups of municipalities are similar across a variety of observable characteristics, excluding media, unemployment and the share of the population with a university degree. The table also shows that municipalities in which there is no weather station are no more corrupt compared to those in which there is a weather station. ${ }^{40}$

\subsection{Robustness}

We experiment with a different coding approach for our dependent variable in Table A6. In column (1), we calculate our corruption index using principal component analysis, which produces a slightly smaller but still statistically significant coefficient. In column (2), our dependent variable is a corruption index calculated using data provided by the Public Financial

\footnotetext{
${ }^{39}$ Mediapool.bg at http://www.mediapool.bg/firmi-na-dps-usvoyavali-zle-parite-za-ukrepvane -sled-starite-poroi-news115354.html. Many rivers were also diverted without any control, and the supervision of water dams was often lax, leading to water volumes frequently being increased over the legal limit.

${ }^{40}$ The first group of municipalities received more flood-related funds per capita, despite experiencing the same level of rainfall and having fewer settlements near water. This suggests that our interpolation procedure should produce estimates which can be treated as lower bounds on the true effect of flood funds on corruption. This is exactly what we find in Table A4, which replicates the baseline specification excluding those municipalities in which rainfall is interpolated and shows that the coefficient on funds received increases. We further explore the endogeneity of weather station locations in Table A5, where we exploit the fact that before 1989, the number of weather stations was nearly double compared to today. We examine to what extent municipalities in which weather stations were closed were different from those in which weather stations still exist today. Importantly, the table shows that while municipalities differ on some of the same observables as in Table A3, historical and contemporary rainfall patterns are very similar for both groups of localities.
} 
Inspection Agency (PFIA). As we explained above, this body is not politically independent, so its audit data may be less reliable as compared to the BNAA reports. Indeed, the coefficient on funds received is positive but very imprecisely estimated, and the first stage is weaker. This is what we would expect if the agency were shielding wrong-doers. In column (3), we account for mayor characteristics (margin with which the mayor was elected in the 2003 elections, and a dummy for whether the mayor was in politics prior to 2003), which has little effect on the results. In column (4), we employ an alternative measure of rainfall, using only those months in 2004 and 2005 for which the change in rainfall, relative to the historical average, was at least 50\% (in unreported specifications, we also experiment with cutoffs of $10 \%, 20 \%$ and $40 \%$, without difference to the results). The point estimate is now slightly stronger, implying that a $10 \%$ increase in funds received leads to a 0.08 points increase in the corruption index, or $10.1 \%$ relative to the sample mean. Finally, our results are robust to including log of total funds along with log funds per capita (column 5, OLS), which shows that municipalities which received more funds were not audited more intensely. ${ }^{41}$

Furthermore, we use additional data from the the Life in Transition Survey (LiTS), a household survey which includes questions ranging from demographics and income to attitudes and perceptions of institutions, to further probe the effects of the natural disaster and associated transfers on corruption perceptions. We exploit the fact that the survey was conducted in Bulgaria in late September 2006, shortly after the BNAA and PFIA audit reports were publicized extensively in the media. ${ }^{42}$ The regressions are reported in Table A7 in the online Appendix, though results should be interpreted as suggestive only due to the small number of municipalities covered in the LiTS (37). Using the same instrumentation strategy as in our baseline specification, we find evidence that respondents reported higher

\footnotetext{
${ }^{41}$ Of course, the results in column (5) should be interpreted as suggestive only, since funds and funds per capita are correlated, and results are estimated via OLS.

${ }^{42}$ Further details on the Life in Transition Survey, and the full data set, can be accessed at http:// www.ebrd.com/what-we-do/economic-research-and-data/data/lits.html.
} 
perceived corruption in municipalities which received more flood-related assistance. These results help confirm the validity of our corruption measures from a perception-based perspective. In addition, they suggest that fraud may result not only in the immediate deflection of public resources but also in lingering perceptions of heightened local corruption more generally. Moreover, we also evidence that people living in municipalities which received more flood-related assistance are more trusting of (local or national) institutions and other people. This indicates that the natural disaster may have encouraged pro-social behavior which could have deterred corruption, implying that our estimates of the effect of transfers on corruption could be treated as a lower bound (compared to transfers which occur in the absence of a flood).

\subsection{Suggestive mechanisms: re-election and heterogeneity of ef- fects}

Although lack of longitudinal data and information on how politicians spent the stolen funds prevents us from distinguishing precisely among the mechanisms driving politicians' decisions, we can nevertheless study to what extent corruption affected re-election of the incumbent mayor in the 2007 municipal elections in Tables 3 and 4 (using probit specifications). This exercise is important in evaluating the extent to which democratic accountability may serve as a brake on corrupt activities. For example, in Brazil where mayors can only serve a maximum of two terms, Ferraz and Finan (2011) find that mayors with re-election incentives are significantly less corrupt than those without reelection incentives. These findings provide support for a political agency model of electoral accountability (Ferejohn, 1986). In Romania, Klašnja (2015) shows that corruption significantly reduces the re-election of incumbents. Are these findings universally applicable to other corrupt countries such as Bulgaria? And is the link between corruption and re-election stronger in instances when the incumbent was 
elected with a narrow margin, which would imply a higher dependency on voters?

In both tables, we try to purge the corruption index of endogeneity by constructing its predicted value using the results in Table $1 .{ }^{43}$ Columns (1) and (2) of Table 3 show that mayors from more corrupt municipalities were marginally less likely to run for re-election, possibly because they anticipated voter punishment at the polls. An alternative explanation is that some incumbents might simply have no need to seek re-election if they were able to embezzle enough money. Columns (3) and (4) demonstrate that corruption is not a significant predictor of mayor re-election. Moreover, local politics have a strong element of persistence: mayors who were in politics before 2003 were more than 70 percentage points more likely to be re-elected.

In Table 4, we replicate the results in Table 3 on the sub-sample of close elections, which we define as those in which the 2003 mayor was elected with a margin of less than $10 \% .{ }^{44}$ The effect of corruption on the decision to run for re-election is now stronger: a one-point increase in the BNAA corruption index (holding all other variables constant) makes mayors around 7 percentage points less likely to run for re-election. However, columns (3) and (4) show that those mayors who did decide to run were more likely to be re-elected. One explanation could be that these are mayors with less excessive corruption violations who use mis-appropriated funds to buy off key voters, although this is admittedly speculative since we lack information on how corrupt politicians spent what they stole. ${ }^{45}$

In Table A8, we further investigate if the effect of flood aid on corruption is conditional on municipal characteristics. This is important not also for validating previous studies linking windfalls and corruption, but also for fine-tuning policies for fighting corruption in such

\footnotetext{
${ }^{43}$ Results are similar if we simply include sequentially rainfall, funds and corruption in an OLS regression.

${ }^{44}$ Unfortunately, smaller cut-offs shrink our sample considerably.

${ }^{45}$ In unreported results, we also investigated whether municipal corruption affected the mayor's party's electoral performance in the 2009 general elections and found no significant effects. We also did not find that voters with more education or those located in municipalities with a stronger media were more likely to punish corrupt mayors.
} 
circumstances. In columns 1 and 2, we rerun our baseline regression (using column (4) from Table 1) on the subsample of municipalities whose municipal income per capita is below the median (column (1)) and above the median (column (2)). In columns (3)-(6) we implement the same approach for unemployment and per-capita newspaper circulation.

Because we split the sample using endogenous variables, results should be interpreted as suggestive and simply as correlations. Furthermore, one needs to keep in mind that dividing the sample in this way eliminates useful variation and, in several cases, weakens our firststage IV results. At the same time, this exercise is informative since it may shed some light on where exactly the effects identified in our baseline specifications are coming from.

More precisely, the estimates in Table A8 indicate that the negative link between funds and governance identified earlier is stronger in municipalities which are richer, with less unemployment, and with fewer newspapers. One potential explanation could be that such municipalities may be less likely to hold governments accountable to spending infringements. Corruption may become less salient for voters when the size of the pie is bigger as in Brollo et al. (2013), while imperfectly informed voters may be less likely to punish dishonest politicians (Ferraz \& Finan, 2008).

When it comes to mechanisms, suggestive evidence implies that corruption had little effect on the re-election chances of the incumbent mayor. This is partly due to the fact that mayors in high-corruption municipalities were less likely to run for re-election, with a stronger effect in municipalities in which the incumbent had previously won by a narrow margin. More tentatively, we find that the link between funds and corruption varies with municipal characteristics. The negative impact of flood assistance on governance is stronger in municipalities which are more developed economically and which have a weaker media. All in all, this suggestive evidence indicates that political accountability informs the decision to steal: mayors engage in corrupt behavior when they feel they can get away with it, or when the prize of stealing more outweighs the benefit of running for office again. In addition, 
few seem to be worried about legal prosecution, as only a handful of corrupt politicians were subject to legal action.

\section{Conclusion}

In this paper, we exploit a unique policy outcome - transfers from Bulgaria's central government to municipalities intended to aid reconstruction following torrential rain in 2004 and 2005. We leverage exogenous variation in allocated funds to demonstrate that unexpected windfalls were not merely allocated to more corrupt places, but rather that increased disaster aid led to more corrupt spending by local governments. Disaster relief fosters corruption, and corruption decreases welfare (Djankov, Nikolova, \& Zilinsky, 2016).

Scholars have long debated the perils of unearned income. We add to the debate findings about how a particular type of unearned income, disaster-relief protection by the central government, affects the quality of governance. Our findings rest on a clever empirical strategy, and offer some insights on the theoretical issues at stake. Key contributions of our study are the plausibly objective measure of misused funds, which we call corruption, and an arguably identified research design, relying on historical deviation of local rainfall. Our findings generate a number of implications for theory and practice.

We highlight the value of creating independent budgetary watch-dogs. Agency control matters, and can generate the kind of transparency that constitutes a necessary condition for public control over local politicians. As in the case of central banks, removing politicians from budgetary watchdogs is a must.

Our finding that local governments are tempted to pocket at least some of the disaster relief indicates that vital reconstruction efforts may be stalled. The embezzled transfers in the cases we study were large enough, so that, if directed toward political machines, could have helped "buy elections" (and so decrease accountability even more) in a number 
of municipalities. ${ }^{46}$ In addition, our finding that voters are less likely to punish mayors in richer municipalities and in those with poor media indicates that rent-seeking depends on the size of the pie and the quality of political accountability, as predicted by work on Brazil.

Although the analysis is focused on a single country and covers a relatively narrow time period, we believe that our findings are relevant for a broader set of developing and transition countries in which financial windfalls, whether derived from natural resources or not, are high. Many countries redistribute public funds, such as foreign aid or budgetary transfers, to the local level. That may be fine for a country with strong institutions such as Germany. Elsewhere, our results imply that continuing such transfers without strengthening mechanisms of control, such as the legal system which has the ability to go after wrong-doers, can create and deepen tendencies to engage in fraud. Private flood insurance may be an appropriate solution where governance is weak.

\section{References}

Achen, C. H., \& Bartels, L. M. (2004). Blind Retrospection. Electoral Responses to Drought, Flu, and Shark Attacks. Working paper.

Ahmed, F. Z. (2013). Remittances Deteriorate Governance. Review of Economics and Statistics, 95(4), 1166-1182.

Aidt, T. S. (2003). Economic Analysis of Corruption: A Survey. Economic Journal, $113(491)$, F632-F652.

Bechtel, M., \& Mannino, M. (2015). Prepare or Relief? Disaster Policy Preferences after a Millennium Flood. manuscript. (Freeman Spogli Institute, Stanford University)

Bechtel, M. M., \& Hainmueller, J. (2011). How Lasting Is Voter Gratitude? An Analysis of the Short-and Long-Term Electoral Returns to Beneficial Policy. American Journal of Political Science, 55(4), 852-868.

Bermeo, S. B. (2011). Foreign Aid and Regime Change: A Role for Donor Intent. World Development, $39(11), 2021-2031$.

Bertrand, M., Djankov, S., Hanna, R., \& Mullainathan, S. (2007). Obtaining a Driver's License in India: an Experimental Approach to Studying Corruption. Quarterly Journal of Economics, 1639-1676.

\footnotetext{
${ }^{46}$ See data available from one of Bulgaria's leading bloggers (Boyan Yurukov at http://yurukov.net/ $\mathrm{blog} /$ ) which show that even a few thousand Euros can be pivotal in many Bulgarian local elections.
} 
Brollo, F., \& Nannicini, T. (2012). Tying your Enemy's Hands in Close Races: The Politics of Federal Transfers in Brazil. American Political Science Review, 106(04), 742-761.

Brollo, F., Nannicini, T., Perotti, R., \& Tabellini, G. (2013). The Political Resource Curse. American Economic Review, 103(5), 1759-1796.

Carnegie, A., \& Marinov, N. (2016). Foreign Aid, Human Rights and Democracy Promotion: Evidence from a Natural Experiment. American Journal of Political Science. (forthcoming)

Caselli, F., \& Michaels, G. (2013). Do Oil Windfalls Improve Living Standards? Evidence from Brazil. American Economic Journal: Applied Economics, 5(1), 208-238.

De La O, A. (2013). Do Conditional Cash Transfers Affect Electoral Behavior? Evidence from a Randomized Experiment in Mexico. American Journal of Political Science, $57(1), 1-14$.

Dell, M., Jones, B. F., \& Olken, B. A. (2014). What Do We Learn from the Weather? The New Climate-Economy Literature. Journal of Economic Literature, 52(3), 740-98.

Dietrich, S. (2016). Donor Political Economies and the Pursuit of Aid Effectiveness. International Organization, 70(1), 65-102.

Djankov, S., Nikolova, E., \& Zilinsky, J. (2016). The happiness gap in eastern europe. Journal of Comparative Economics, 44 (1), 108-124.

Dunning, T. (2008). Crude democracy: Natural resource wealth and political regimes. Cambridge University Press.

Duru, M. (2016). Too Certain to Invest? The Political Economy of Ethiopian Insurance Markets. World Development. (forthcoming)

Ferejohn, J. (1986). Incumbent Performance and Electoral Control. Public choice, 50(1), $5-25$.

Ferraz, C., \& Finan, F. (2008). Exposing Corrupt Politicians: The Effects of Brazil's Publicly Released Audits on Electoral Outcomes. Quarterly Journal of Economics, 123(2), 703-745.

Ferraz, C., \& Finan, F. (2011). Electoral Accountability and Corruption: Evidence from the Audits of Local Governments. American Economic Review, 101, 1274-1311.

Findley, M. G., Nielson, D. L., \& Sharman, J. C. (in press). Causes of Non-Compliance with International Law: Evidence from a Field Experiment on Anonymous Incorporation. American Journal of Political Science.

Fisman, R., \& Miguel, E. (2007). Corruption, Norms, and Legal Enforcement: Evidence from Diplomatic Parking Tickets. Journal of Political Economy, 115(6), 1020-1048.

Gervasoni, C. (2010). A Rentier Theory of Subnational Regimes: Fiscal Federalism, Democracy, and Authoritarianism in the Argentine Provinces. World Politics, 62 (02), 302340.

Guiteras, R., \& Mobarak, A. M. (2014). Does Development Aid Undermine Political Accountability? Leader and Constituent Responses to a Large-Scale Intervention. Working paper, Yale University.

Haber, S., \& Menaldo, V. (2011). Do Natural Resources Fuel Authoritarianism? A Reappraisal of the Resource Curse. American Political Science Review, 105(01), 1-26. 
Jensen, N., \& Wantchekon, L. (2004). Resource Wealth and Political Regimes in Africa. Comparative Political Studies, 37(7), 816-841.

Klašnja, M. (2015). Corruption and Incumbency disadvantage: Theory and Evidence. The Journal of Politics, $77(04)$, 928-942.

Koleva, E., \& Peneva, R. (1990). Klimatichen Spravochnik (Valeji v Bulgaria) - in Bulgarian. Bulgarian Academy of Sciences, Sofia.

Kosec, K., \& Mo, C. H. (2015, October). Aspirations and the Role of Social Protection: Evidence from a Natural Disaster in Rural Pakistan. http://ebrary. ifpri.org/cdm/ ref/collection/p15738coll2/id/129692. (IFPRI Discussion Paper 01467)

Krasner, S. D., \& Weinstein, J. M. (2014). Improving Governance from the Outside In. Annual Review of Political Science, 17, 123-145.

Lazarev, Y., Sobolev, A., Soboleva, I., \& Sokolov, B. (2014). Trial by Fire: a Natural Disaster's Impact on Support for the Authorities in Rural Russia. World Politics, $66(4), 641-668$.

Litschig, S., \& Morrison, K. M. (2013). The Impact of Intergovernmental Transfers on Education Outcomes and Poverty Reduction. American Economic Journal: Applied Economics, 5(4), 206-240.

Manacorda, M., Miguel, E., \& Vigorito, A. (2011). Government Transfers and Political Support. American Economic Journal: Applied Economics, 3(3), 1-28.

Miguel, E., Satyanath, S., \& Sergenti, E. (2004). Economic Shocks and Civil Conflict: An Instrumental Variables Approach. Journal of Political Economy, 112(4), 725-753.

Milner, H., Nielson, D., \& Findley, M. (2016). Citizen Preferences and Public Goods: Comparing Preferences for Foreign Aid and Government Programs in Uganda. Review of International Organizations.

Mironov, M., \& Zhuravskaya, E. (2014). Corruption in Procurement: Evidence from Financial Transactions Data. Unpublished working paper. Social Science Research Network.

Monteiro, J., \& Ferraz, C. (2010). Does Oil Make Leaders Unaccountable? Evidence from Brazils Offshore Oil Boom. Working paper, PUC-Rio.

Morrison, K. (2012). What Can We Learn about the "Resource Curse" from Foreign Aid? World Bank Research Observer, 27(1), 52-73.

Olken, B. (2007). Monitoring Corruption: Evidence from a Field Experiment in Indonesia. Journal of Political Economy, 115(2), 1-28.

Olken, B. A. (2009). Corruption perceptions vs. Corruption Reality. Journal of Public Economics, 93(7), 950-964.

Pop-Eleches, C., \& Pop-Eleches, G. (2012). Targeted Government Spending and Political Preferences. Quarterly Journal of Political Science, 7(3), 285-320.

Quiroz Flores, A., \& Smith, A. (2013). Leader Survival and Natural Disasters. British Journal of Political Science, 43(04), 821-843.

Ramsay, K. W. (2011). Revisiting the Resource Curse: Natural Disasters, the Price of Oil, and Democracy. International Organization, 65(03), 507-529.

Reinikka, R., \& Svensson, J. (2005). Fighting Corruption to Improve Schooling: Evidence from a Newspaper Campaign in Uganda. Journal of the European Economic Associa- 
tion, 3(2-3), 259-267.

Robertson, G. (2015). Political orientation, information and perceptions of election fraud: Evidence from russia. British Journal of Political Science, FirstView, 1-20. doi: 10.1017/S0007123415000356

Rose-Ackerman, S. (1999). Corruption and Government: Causes, Consequences, and Reform. Cambridge University press.

Smith, A. (2008). The Perils of Unearned Income. The Journal of Politics, 70 (03), 780-793.

Soós, G., Tóka, G., \& Wright, G. (2002). The State of Local Democracy in Central Europe. Local Government and Public Service Reform Initiative, Open Society Institute.

UNDP. (2002). Bulgaria Human Development Index: Municipalities in the Context of Districts. United Nations Development Program, Sofia.

Vicente, P. C. (2010). Does Oil Corrupt? Evidence from a Natural Experiment in West Africa. Journal of Development Economics, 92(1), 28-38. 
Figure 1: Precipitation deviations (relative to a historical average), by month and municipality, 2004-2005

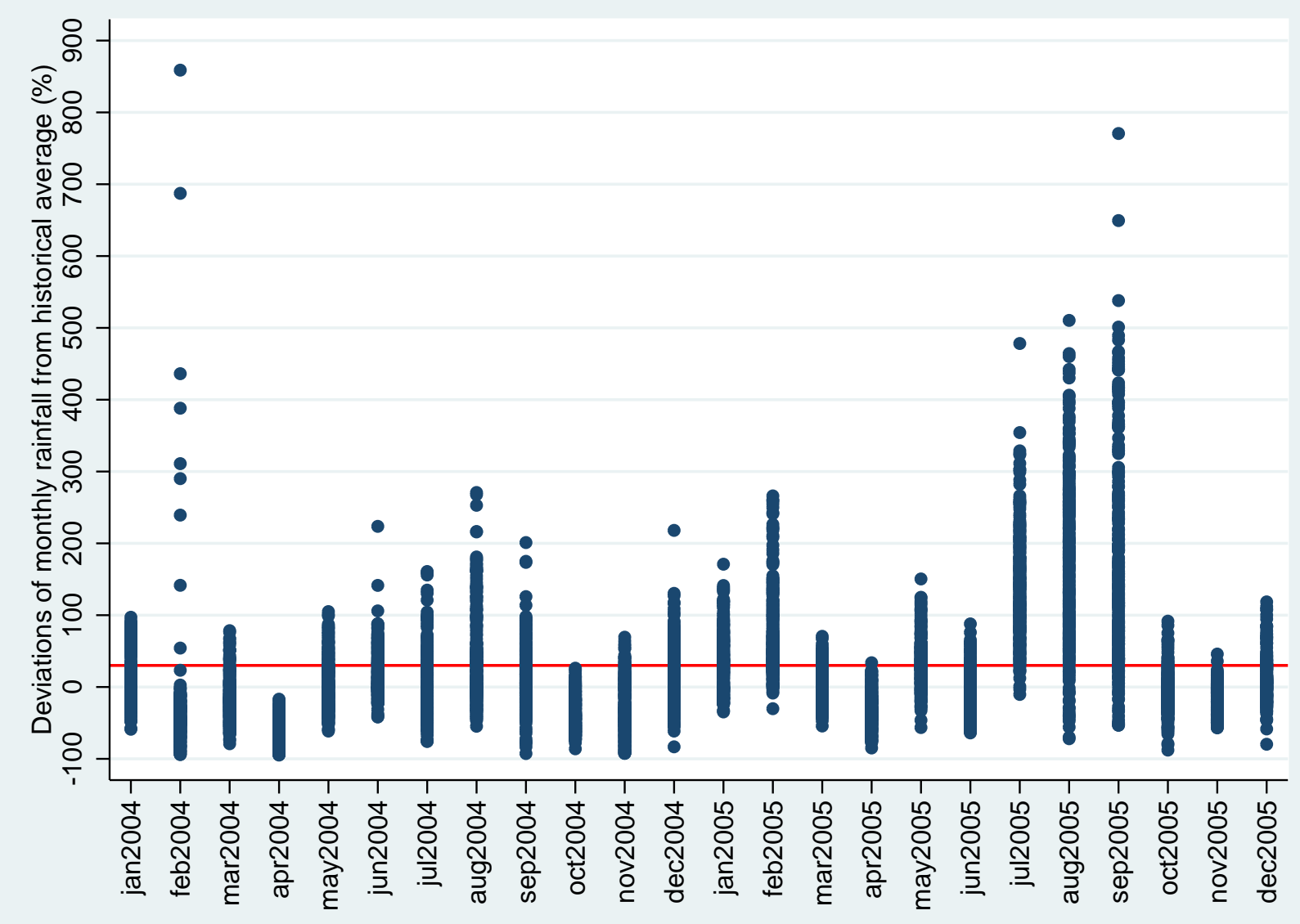


Table 1: Public funds and corruption: Baseline specification

\begin{tabular}{|c|c|c|c|c|c|}
\hline & \multicolumn{2}{|c|}{ OLS } & \multicolumn{2}{|c|}{ IV } & \multirow{2}{*}{$\frac{\text { IV-Poisson }}{(5)}$} \\
\hline & $\begin{array}{c}(1) \\
\text { BNAA }\end{array}$ & $\begin{array}{c}(2) \\
\text { BNAA }\end{array}$ & $\begin{array}{c}(3) \\
\text { BNAA }\end{array}$ & $\begin{array}{c}(4) \\
\text { BNAA }\end{array}$ & \\
\hline log funds per cap & $\begin{array}{l}0.268^{* * *} \\
(0.0913)\end{array}$ & $\begin{array}{l}0.261^{* * *} \\
(0.0903)\end{array}$ & $\begin{array}{l}0.908^{* * *} \\
(0.310)\end{array}$ & $\begin{array}{l}0.793^{* * *} \\
(0.280)\end{array}$ & $\begin{array}{l}0.691^{* * *} \\
(0.238)\end{array}$ \\
\hline Geography & $\checkmark$ & $\checkmark$ & $\checkmark$ & $\checkmark$ & $\checkmark$ \\
\hline Economic conditions & $\checkmark$ & $\checkmark$ & $\checkmark$ & $\checkmark$ & $\checkmark$ \\
\hline Civil society & $\checkmark$ & $\checkmark$ & $\checkmark$ & $\checkmark$ & $\checkmark$ \\
\hline Composition of local gov. & & $\checkmark$ & & $\checkmark$ & $\checkmark$ \\
\hline $\begin{array}{l}\text { F-stat. } \\
\text { rainfall \% deviation, } 30 \% \text { cutoff }\end{array}$ & & & $\begin{array}{c}17.75 \\
1.106 \\
(0.263)\end{array}$ & $\begin{array}{c}18.52 \\
1.127 \\
(0.262)\end{array}$ & \\
\hline R-sq & 0.190 & 0.215 & & & \\
\hline Number of observations & 225 & 225 & 225 & 225 & 225 \\
\hline
\end{tabular}

Notes: Regional dummies are included in all specifications. Robust standard errors are in parentheses. Last column reports marginal effects from an IV-Poisson regression. Significance levels: ${ }^{*} p<0.1,{ }^{* *} p<0.05,{ }^{* * *} p<0.01$. 
Table 2: Public funds and corruption: first-stage results

\begin{tabular}{|c|c|c|c|}
\hline & $\begin{array}{c}(1) \\
\log \text { funds per cap }\end{array}$ & $\begin{array}{c}(2) \\
\log \text { funds per cap }\end{array}$ & $\begin{array}{c}(3) \\
\log \text { funds per cap }\end{array}$ \\
\hline rainfall $\%$ deviation, $30 \%$ cutoff & $\begin{array}{l}1.106^{* * *} \\
(0.263)\end{array}$ & $\begin{array}{l}1.127^{* * *} \\
(0.262)\end{array}$ & $\begin{array}{l}1.171^{* * *} \\
(0.273)\end{array}$ \\
\hline distance to BNAA regional center & $\begin{array}{c}-0.00468^{* *} \\
(0.00189)\end{array}$ & $\begin{array}{c}-0.00458^{* *} \\
(0.00192)\end{array}$ & $\begin{array}{c}-0.00488^{* *} \\
(0.00193)\end{array}$ \\
\hline elevation & $\begin{array}{c}0.000347 \\
(0.000361)\end{array}$ & $\begin{array}{c}0.000384 \\
(0.000366)\end{array}$ & $\begin{array}{c}0.000370 \\
(0.000363)\end{array}$ \\
\hline relief slope & $\begin{array}{c}0.0319 \\
(0.0224)\end{array}$ & $\begin{array}{c}0.0295 \\
(0.0230)\end{array}$ & $\begin{array}{c}0.0290 \\
(0.0224)\end{array}$ \\
\hline longitude & $\begin{array}{r}0.0625 \\
(0.178)\end{array}$ & $\begin{array}{r}0.0646 \\
(0.180)\end{array}$ & $\begin{array}{r}0.0636 \\
(0.179)\end{array}$ \\
\hline latitude & $\begin{array}{l}0.103 \\
(0.0874)\end{array}$ & $\begin{array}{l}0.113 \\
(0.0933)\end{array}$ & $\begin{array}{c}0.0768 \\
(0.0916)\end{array}$ \\
\hline settlements near water & $\begin{array}{c}0.00310 \\
(0.00627)\end{array}$ & $\begin{array}{c}0.00346 \\
(0.00645)\end{array}$ & $\begin{array}{c}0.00289 \\
(0.00640)\end{array}$ \\
\hline log muncipal income per capita & $\begin{array}{l}0.684^{* * *} \\
(0.223)\end{array}$ & $\begin{array}{l}0.679^{* * *} \\
(0.228)\end{array}$ & $\begin{array}{l}0.692^{* * *} \\
(0.222)\end{array}$ \\
\hline unemployment & $\begin{array}{r}0.000980 \\
(0.00730)\end{array}$ & $\begin{array}{r}0.000773 \\
(0.00740)\end{array}$ & $\begin{array}{c}-0.000635 \\
(0.00758)\end{array}$ \\
\hline net privatization income & $\begin{array}{c}0.00281 \\
(0.00574)\end{array}$ & $\begin{array}{c}0.00352 \\
(0.00595)\end{array}$ & $\begin{array}{c}0.00274 \\
(0.00597)\end{array}$ \\
\hline newspaper circ. per capita & $\begin{array}{c}0.000256 \\
(0.000251)\end{array}$ & $\begin{array}{c}0.000223 \\
(0.000246)\end{array}$ & $\begin{array}{c}0.000299 \\
(0.000255)\end{array}$ \\
\hline university degree & $\begin{array}{c}-10.57^{* * *} \\
(2.031)\end{array}$ & $\begin{array}{c}-10.69^{* * *} \\
(2.062)\end{array}$ & $\begin{array}{c}-10.57^{* * *} \\
(2.038)\end{array}$ \\
\hline share urban population & $\begin{array}{r}-0.410^{*} \\
(0.217)\end{array}$ & $\begin{array}{r}-0.416^{*} \\
(0.217)\end{array}$ & $\begin{array}{r}-0.384^{*} \\
(0.222)\end{array}$ \\
\hline voter turnout 2003 & $\begin{array}{c}0.680^{*} \\
(0.395)\end{array}$ & $\begin{array}{r}0.696^{*} \\
(0.397)\end{array}$ & $\begin{array}{c}0.634 \\
(0.404)\end{array}$ \\
\hline mayor triple coal. & & $\begin{array}{c}-0.123 \\
(0.152)\end{array}$ & \\
\hline council majority triple coal. & & $\begin{array}{c}-0.173 \\
(0.207)\end{array}$ & \\
\hline mayor \& council triple coal. & & $\begin{array}{c}0.212 \\
(0.243)\end{array}$ & \\
\hline mayor MRF & & & $\begin{array}{c}0.172 \\
(0.152)\end{array}$ \\
\hline council majority MRF & & & $\begin{array}{c}0.0705 \\
(0.362)\end{array}$ \\
\hline mayor\&council MRF & & & $\begin{array}{r}-0.0547 \\
(0.407)\end{array}$ \\
\hline Region dummies & $\checkmark$ & $\checkmark$ & $\checkmark$ \\
\hline $\begin{array}{l}\text { R-sq } \\
\text { Number of observations }\end{array}$ & $225^{0.50^{4}}$ & $\begin{array}{l}0.526 \\
225\end{array}$ & $\begin{array}{l}0.527 \\
225\end{array}$ \\
\hline
\end{tabular}

Notes: Regional dummies are included in all specifications. Robust standard errors are in parentheses. Significance levels: ${ }^{*} p<0.1,{ }^{* *} p<0.05,{ }^{* * *} p<0.01$. 
Table 3: Corruption and mayor re-election (probit)

\begin{tabular}{lcccc}
\hline & $(1)$ & $(2)$ & $(3)$ & $(4)$ \\
& candidate in 2007 & candidate in 2007 & reelected in 2007 & reelected in 2007 \\
\hline predicted BNAA & -0.0267 & $-0.0406^{*}$ & 0.0576 & 0.0455 \\
voter turnout 07 & $(0.0247)$ & $(0.0243)$ & $(0.0432)$ & $(0.0460)$ \\
& 0.00224 & 0.00262 & 0.00223 & 0.00237 \\
margin elected 2003 & $(0.00196)$ & $(0.00193)$ & $(0.00278)$ & $0.00280)$ \\
in politics before 2003 & -0.171 & -0.154 & 0.460 & $(0.340)$ \\
& $(0.252)$ & $(0.261)$ & $(0.336)$ & $0.710^{* * *}$ \\
Geography & $0.190^{* * *}$ & $0.209^{* * *}$ & $0.692^{* * *}$ & $(0.0691)$ \\
Economic conditions & $(0.0386)$ & $(0.0397)$ & $(0.0701)$ & $\checkmark$ \\
Civil society & $\checkmark$ & $\checkmark$ & $\checkmark$ & $\checkmark$ \\
Composition of local gov. & $\checkmark$ & $\checkmark$ & $\checkmark$ & $\checkmark$ \\
\hline Number of observations & 225 & $\checkmark$ & $\checkmark$ & $\checkmark$ \\
\hline
\end{tabular}

Notes: Regional dummies are included in all specifications. Average marginal effects from probit regressions are reported. Robust standard errors are in parentheses. Significance levels: ${ }^{*} p<0.1,{ }^{* *} p<0.05$, $* * * p<0.01$. 
Table 4: Corruption and mayor re-election: close elections (probit)

\begin{tabular}{lcccc}
\hline & $(1)$ & $(2)$ & $(3)$ & $(4)$ \\
& candidate in 2007 & candidate in 2007 & reelected in 2007 & reelected in 2007 \\
\hline predicted BNAA & $-0.0855^{* * *}$ & $-0.0734^{* * *}$ & $0.158^{* * *}$ & $0.170^{* * *}$ \\
voter turnout 07 & $(0.0301)$ & $(0.0207)$ & $(0.0425)$ & $(0.0555)$ \\
& $0.00861^{* * *}$ & $0.00898^{* * *}$ & 0.00421 & 0.00391 \\
margin elected 2003 & $(0.00267)$ & $(0.00244)$ & $(0.00318)$ & $(0.00310)$ \\
& $-1.070^{*}$ & -0.705 & $2.411^{* *}$ & $(0.970)$ \\
in politics before 2003 & $(0.567)$ & $(0.477)$ & $(0.984)$ & $0.704^{* * *}$ \\
Geography & $0.272^{* * *}$ & $0.282^{* * *}$ & $0.676^{* * *}$ & $(0.0739)$ \\
Economic conditions & $(0.0491)$ & $(0.0445)$ & $(0.0631)$ & $\checkmark$ \\
Civil society & $\checkmark$ & $\checkmark$ & $\checkmark$ & $\checkmark$ \\
Composition of local gov. & $\checkmark$ & $\checkmark$ & $\checkmark$ & $\checkmark$ \\
\hline Number of observations & 162 & $\checkmark$ & $\checkmark$ & $\checkmark$ \\
\hline
\end{tabular}

Notes: Regional dummies are included in all specifications. Average marginal effects from probit regressions are reported. Robust standard errors are in parentheses. Close elections hose in which the 2003 mayor was elected with a margin of less than $10 \%$. Significance levels: ${ }^{*} p<0.1,{ }^{* *} p<0.05,{ }^{* * *} p<0.01$. 


\section{ONLINE APPENDIX: NOT FOR PUBLICATION}

\section{A Political background and distribution of flood-related funds}

Bulgaria is a parliamentary republic, whose central government is usually run by coalitions (by virtue of its closed-list proportional system). Until August 2005, flood-relief funds were managed by the Ministry for Agriculture and Forestry and a floating ministry ("without portfolio") controlled by the Movement for Rights and Freedoms (MRF), a party whose electorate comprises mainly Bulgarian Turks. From 2001 to 2005, MRF was part of a ruling coalition led by National Movement Simeon II (NDSV, the party run by Bulgaria's former king, Simeon Sakskoburgotski) which also included the Bulgarian Socialist Party (BSP). Following the 2005 general elections, a "triple" coalition government comprising the same partners but led by the Socialists was formed. In addition to the Ministry for Agriculture and Forestry, MRF also gained control of the Ministry for Environment and Water as well as of a newly formed Ministry for Disasters. All of the latter ministries played a central role in the control and management of flood-related aid disbursed from central government to municipalities.

At the local level, municipal finances are controlled by an elected council (holding the highest authority) which operates along an elected mayor. There are no term limits for either the mayor or the councilors, and local elections, conducted every four years, are usually held two years before general elections (local governments dealing with the 2004-2005 floods were elected in 2003) (Soós, Tóka, \& Wright, 2002). 


\section{B Additional robustness checks}

We further probe the robustness of our results in Table A9. To conserve space, we only present the inclusive version of the model, that is column (4) in Table 1. In Table 1, we did not find evidence that the positive relationship between funds received and corruption can be explained by whether the local government is affiliated with the triple coalition or with MRF. To probe this further, in column (1) of Table A9 we include a triple interaction between local newspapers per capita, and dummies for whether the mayor and the council are affiliated with the triple coalition. The coefficient on log funds per capita remains unchanged from that in Table 1, but there is some evidence that mayors belonging to the triple coalition stole more in municipalities with a stronger media. In addition, municipalities in which the majority of the council was controlled by the ruling coalition were marginally more likely to be corrupt, while higher newspaper circulation and a local government where both the mayor and council belong to the triple coalition are associated with less corruption. ${ }^{47}$ In column (2), we control for a municipality's distance to one of the nearest 28 oblast centers, which is at the NUTS-3 level, with little change to the results. In column (3), we account for the per-capita amount of additional ad-hoc funding received by each municipal government from the central government (in 2003; intended to cover budget deficits for "state affairs"). Once more, results are unchanged.

[Table A9 around here]

\section{Additional figures and tables}

\footnotetext{
${ }^{47}$ Unreported coefficients for column (1): newspapers circ. per capita: -.00085**; mayor triple coal. 0.11529; council majority triple coal: .72516*; mayor and council triple coal: $-.75375^{* *}$. In unreported results, we instead included controls for whether the local government is affiliated with MRF (rather than the broader triple coalition), along with its interaction with newspapers. We obtained very similar results.
} 
Figure A1: Geographical distribution of flood funds (per capita, in BGN)

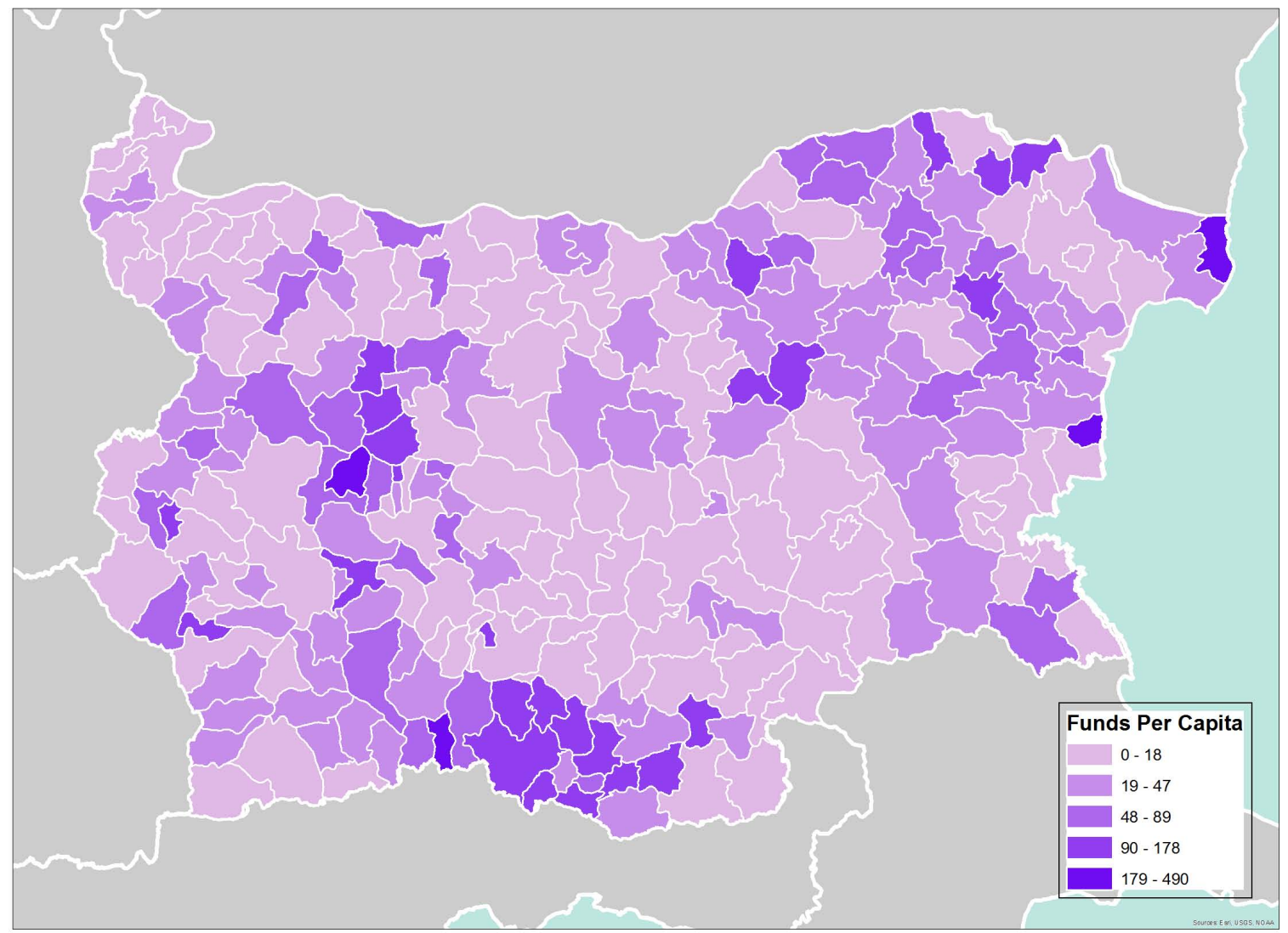


Figure A2: Geographical distribution of corruption infringements: Bulgarian National Audit Agency

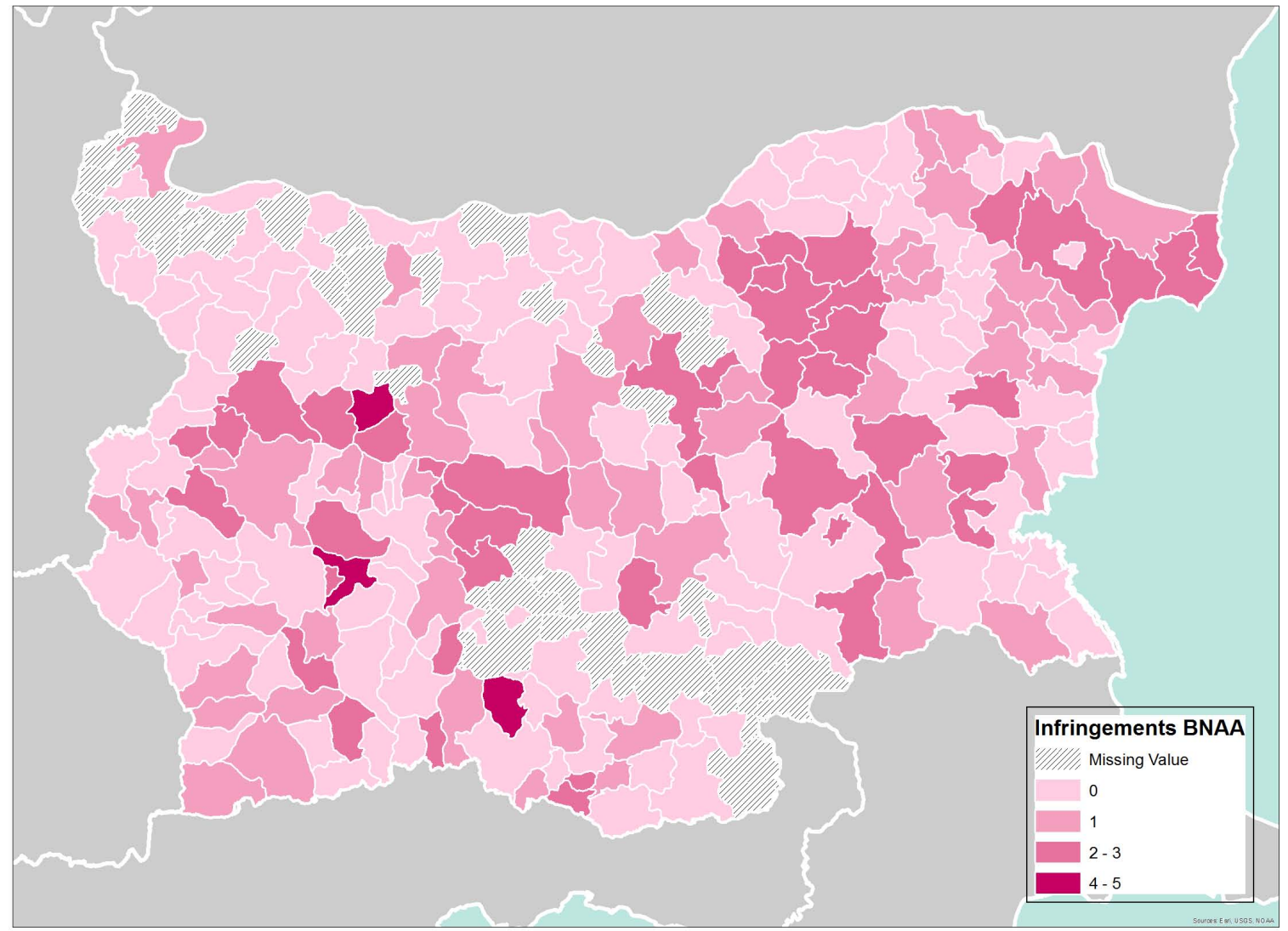


Figure A3: Geographical distribution of corruption infringements: Public Financial Inspection Agency

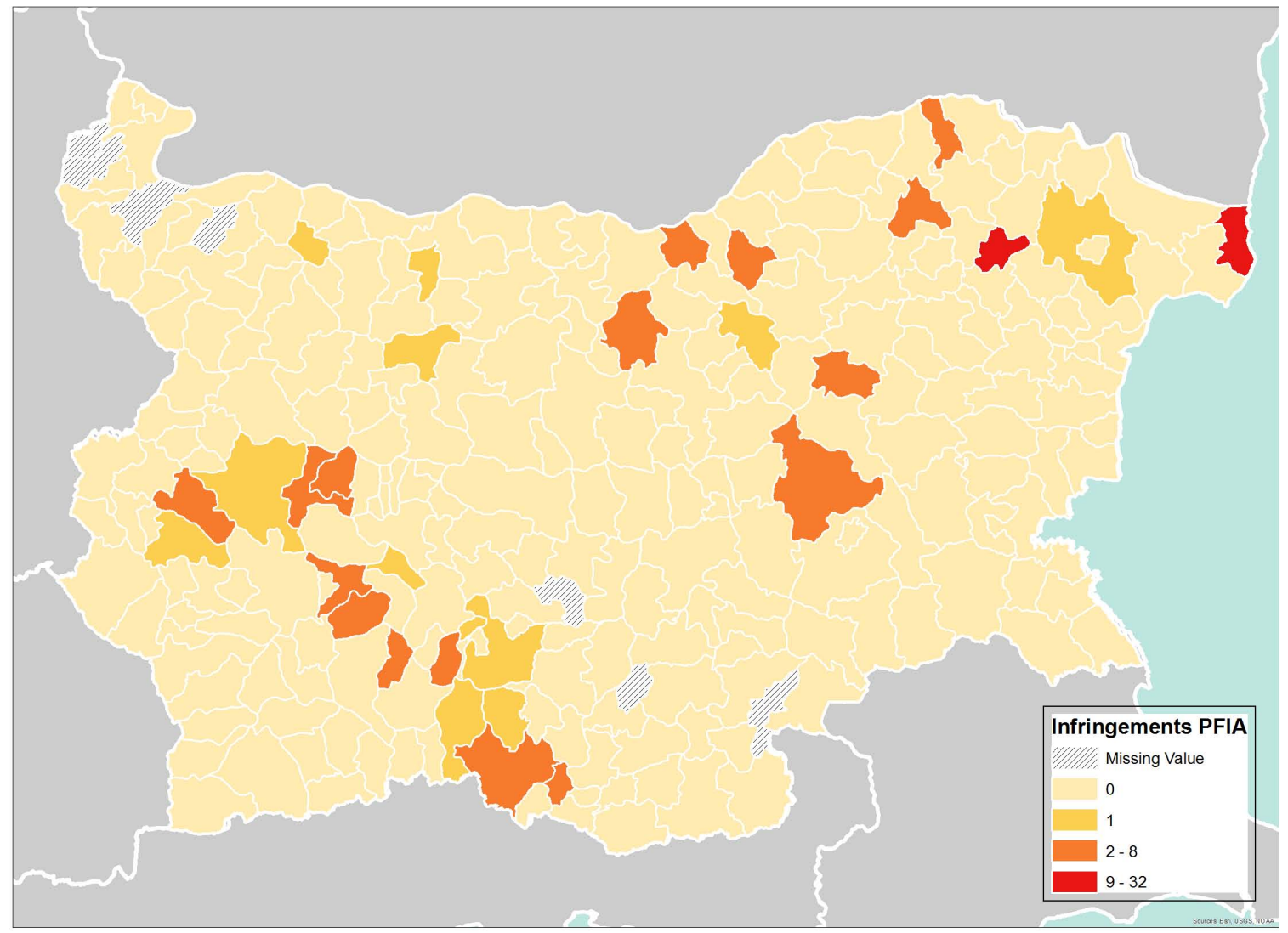


Figure A4: Histogram of BNAA corruption index

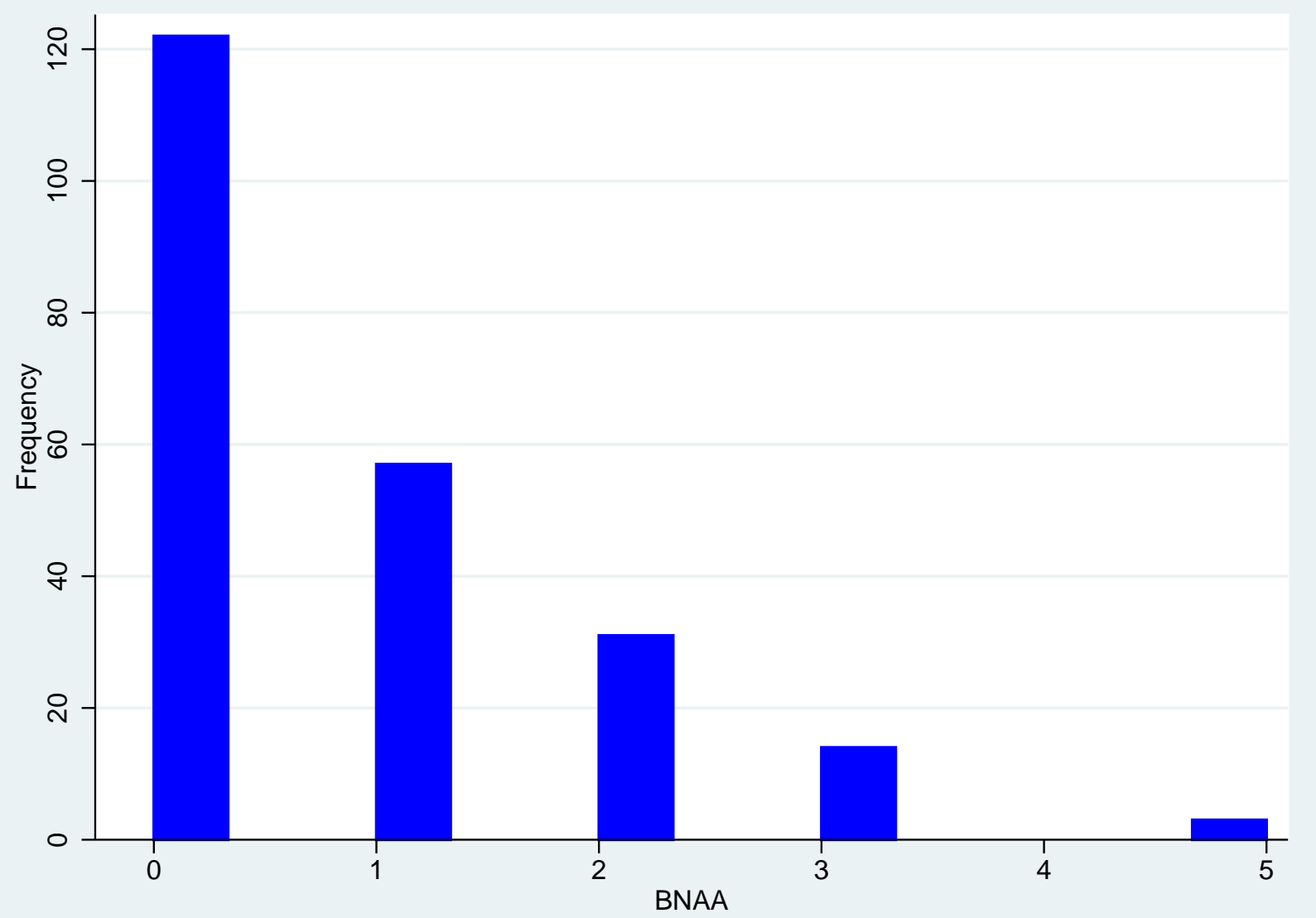


Figure A5: Baseline specification: relationship between Rainfall and Funds in the first stage

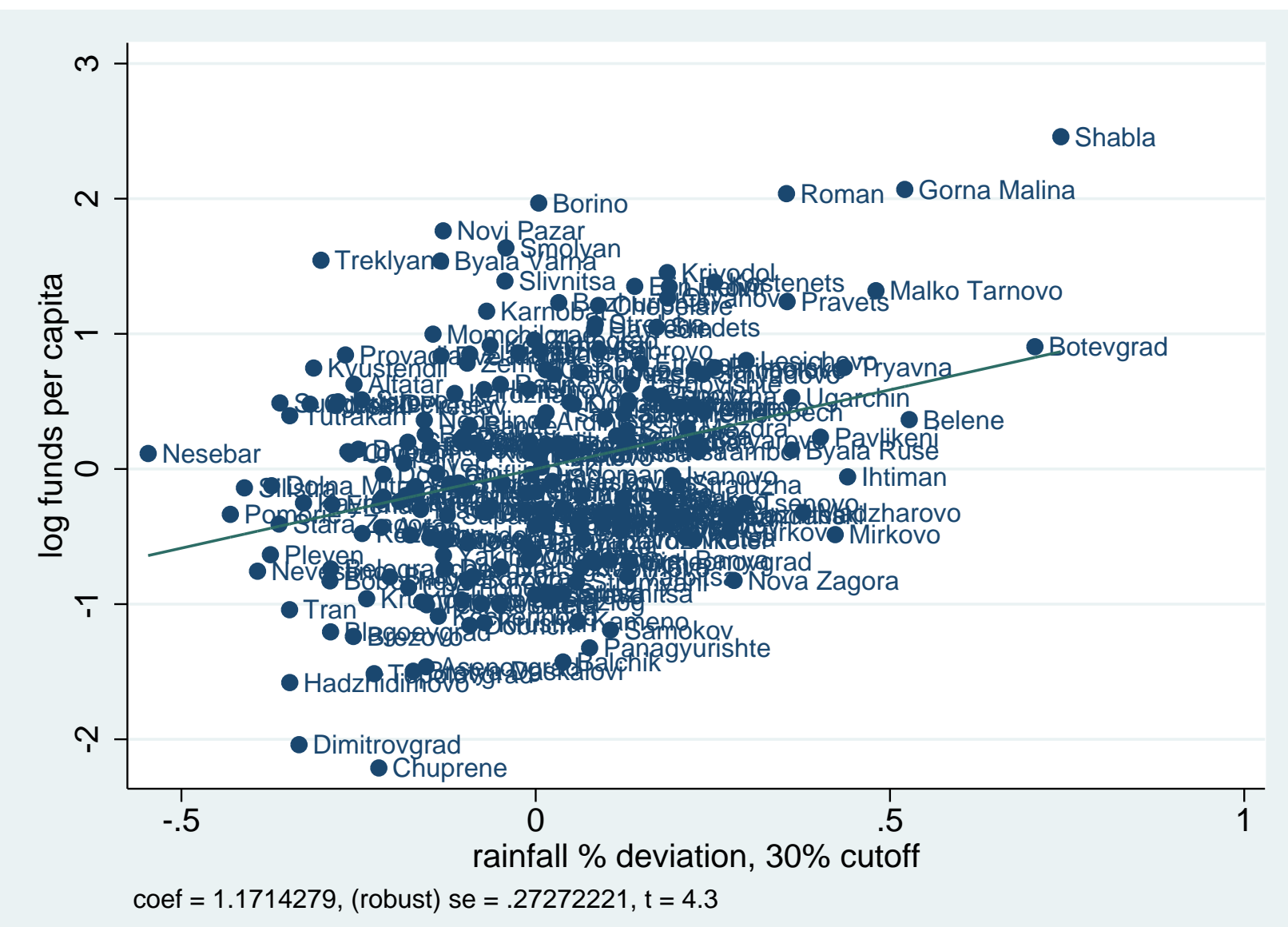


Table A1: Comparison between audited and non-audited municipalities

\begin{tabular}{|c|c|c|c|}
\hline \multirow[t]{2}{*}{ Control of baseline reg. } & \multicolumn{2}{|c|}{ Mean } & \multirow[t]{2}{*}{$t-s t a t$} \\
\hline & audited by BNAA & not audited by BNAA & \\
\hline funds per capita & 43.396 & 10.022 & $3.533^{* * *}$ \\
\hline rainfall $\%$ deviation, $30 \%$ cutoff & 1.070 & 1.124 & -1.128 \\
\hline rainfall $\%$ deviation, $50 \%$ cutoff & 1.381 & 1.429 & -0.725 \\
\hline historical rainfall, $\mathrm{mm}$ & 671.978 & 646.650 & 1.640 \\
\hline \multicolumn{4}{|l|}{ Geography } \\
\hline distance to BNAA regional center & 72.110 & 72.050 & 0.010 \\
\hline elevation & 505.593 & 248.838 & $3.905^{* * *}$ \\
\hline relief slope & 7.534 & 4.380 & $3.905^{* * *}$ \\
\hline longitude & 42.765 & 42.931 & -1.291 \\
\hline latitude & 25.198 & 24.407 & $2.893^{* * *}$ \\
\hline settlements near water & 7.177 & 4.973 & 1.478 \\
\hline \multicolumn{4}{|l|}{ Economic conditions } \\
\hline log muncipal income per capita & 5.467 & 5.438 & 0.658 \\
\hline unemployment & 19.946 & 25.294 & $-3.128^{* * *}$ \\
\hline net privatization income & 4.384 & 2.644 & 1.287 \\
\hline \multicolumn{4}{|l|}{ Civil society } \\
\hline newspaper circ. per capita & 139.237 & 205.978 & -1.518 \\
\hline share university degree & 0.069 & 0.062 & 0.945 \\
\hline share urban population & 0.648 & 0.336 & 0.845 \\
\hline voter turnout 2003 & 0.569 & 0.477 & 0.448 \\
\hline \multicolumn{4}{|l|}{ Composition of local gov. } \\
\hline mayor triple coal. & 0.674 & 0.757 & -1.003 \\
\hline council majority triple coal. & 0.432 & 0.541 & -1.233 \\
\hline mayor \& council triple coal. & 0.348 & 0.432 & -0.990 \\
\hline mayor MRF & 0.163 & 0.027 & $2.196^{* *}$ \\
\hline council majority MRF & 0.119 & 0.027 & $1.686^{*}$ \\
\hline mayor\&council MRF & 0.106 & 0.027 & 1.517 \\
\hline \multicolumn{4}{|l|}{ Mayor characteristics } \\
\hline margin elected 2003 & 0.078 & 0.066 & 1.020 \\
\hline in politics before 2003 & 0.712 & 0.703 & 0.120 \\
\hline
\end{tabular}

Notes: The table compares municipalities which were audited by BNAA with those which were not audited by BNAA. Significance levels: ${ }^{*} p<0.1,{ }^{* *} p<0.05,{ }^{* * *} p<0.01$. 
Table A2: Regressing rainfall on municipal observable characteristics

\begin{tabular}{|c|c|}
\hline & $\begin{array}{c}(1) \\
\text { rainfall } \% \text { deviation, } 30 \% \text { cutoff }\end{array}$ \\
\hline audited & $\begin{array}{c}-0.0284 \\
(0.0512)\end{array}$ \\
\hline distance to BNAA regional center & $\begin{array}{l}0.00274^{* * *} \\
(0.000541)\end{array}$ \\
\hline elevation & $\begin{array}{c}-0.000265^{* * *} \\
(0.0000799)\end{array}$ \\
\hline relief slope & $\begin{array}{l}0.0201^{* * *} \\
(0.00558)\end{array}$ \\
\hline longitude & $\begin{array}{r}0.0939^{*} \\
(0.0556)\end{array}$ \\
\hline latitude & $\begin{array}{l}0.103^{* * *} \\
(0.0259)\end{array}$ \\
\hline settlements near water & $\begin{array}{c}-0.00157 \\
(0.00205)\end{array}$ \\
\hline log muncipal income per capita & $\begin{array}{l}0.000571 \\
(0.0662)\end{array}$ \\
\hline unemployment & $\begin{array}{c}0.00303 \\
(0.00197)\end{array}$ \\
\hline net privatization income & $\begin{array}{c}-0.000165 \\
(0.00187)\end{array}$ \\
\hline newspaper circ. per capita & $\begin{array}{c}-0.0000261 \\
(0.0000500)\end{array}$ \\
\hline university degree & $\begin{array}{c}0.630 \\
(0.701)\end{array}$ \\
\hline share urban population & $\begin{array}{c}0.0601 \\
(0.0529)\end{array}$ \\
\hline voter turnout 2003 & $\begin{array}{c}-0.120 \\
(0.0955)\end{array}$ \\
\hline mayor triple coal. & $\begin{array}{c}0.0561 \\
(0.0427)\end{array}$ \\
\hline council majority triple coal. & $\begin{array}{c}0.0151 \\
(0.0643)\end{array}$ \\
\hline mayor \& council triple coal. & $\begin{array}{c}-0.0959 \\
(0.0738)\end{array}$ \\
\hline margin elected 2003 & $\begin{array}{c}-0.320 \\
(0.233)\end{array}$ \\
\hline in politics before 2003 & $\begin{array}{c}-0.0239 \\
(0.0324)\end{array}$ \\
\hline Budget topup per capita, 2003 & $\begin{array}{c}0.678 \\
(1.530)\end{array}$ \\
\hline Region dummies & $\checkmark$ \\
\hline $\begin{array}{l}\text { R-sq } \\
\text { Number of observations }\end{array}$ & $\begin{array}{l}0.378 \\
260\end{array}$ \\
\hline
\end{tabular}

Notes: Regional dummies are included in all specifications. Robust standard errors are in parentheses. Significance levels: ${ }^{*} p<0.1,{ }^{* *}$ $p<0.05,{ }^{* * *} p<0.01$. 
Table A3: Comparison between municipalities with and without weather stations

\begin{tabular}{|c|c|c|c|}
\hline & \multicolumn{2}{|c|}{ Mean } & \multirow[t]{2}{*}{$t-s t a t$} \\
\hline & Interpolation & No interpolation & \\
\hline BNAA & 0.691 & 0.909 & -1.543 \\
\hline funds per capita & 44.084 & 29.174 & $2.151^{* *}$ \\
\hline rainfall $\%$ deviation, $30 \%$ cutoff & 1.070 & 1.091 & -0.594 \\
\hline rainfall $\%$ deviation, $50 \%$ cutoff & 1.378 & 1.404 & -0.544 \\
\hline historical rainfall, $\mathrm{mm}$ & 671.909 & 662.236 & 0.863 \\
\hline \multicolumn{4}{|l|}{ Geography } \\
\hline distance to BNAA regional center & 70.868 & 74.295 & -0.792 \\
\hline elevation & 466.542 & 474.653 & -0.166 \\
\hline relief slope & 7.110 & 7.054 & 0.093 \\
\hline longitude & 42.793 & 42.778 & 0.159 \\
\hline latitude & 24.997 & 25.248 & -1.249 \\
\hline settlements near water & 5.381 & 9.495 & $-3.904^{* * *}$ \\
\hline \multicolumn{4}{|l|}{ Economic conditions } \\
\hline$\overline{\log \text { muncipal income }}$ per capita & 5.472 & 5.447 & 0.824 \\
\hline unemployment & 21.866 & 18.635 & $2.596^{* * *}$ \\
\hline net privatization income & 4.170 & 4.087 & 0.085 \\
\hline \multicolumn{4}{|l|}{ Civil society } \\
\hline newspaper circ. per capita & 192.707 & 70.110 & $3.951^{* * *}$ \\
\hline share university degree & 0.055 & 0.091 & $-8.045^{* * *}$ \\
\hline share urban population & 0.631 & 0.557 & 0.279 \\
\hline voter turnout 2003 & 0.629 & 0.426 & 1.372 \\
\hline \multicolumn{4}{|l|}{ Composition of local gov. } \\
\hline$\overline{\text { mayor triple coal. }}$ & 0.710 & 0.642 & 1.140 \\
\hline council majority triple coal. & 0.467 & 0.411 & 0.891 \\
\hline mayor \& council triple coal. & 0.396 & 0.295 & 1.655 \\
\hline mayor MRF & 0.160 & 0.116 & 0.975 \\
\hline council majority MRF & 0.124 & 0.074 & 1.280 \\
\hline mayor\&council MRF & 0.112 & 0.063 & 1.312 \\
\hline \multicolumn{4}{|l|}{ Mayor characteristics } \\
\hline$\overline{\text { margin elected } 2003}$ & 0.077 & 0.075 & 0.317 \\
\hline in politics before 2003 & 0.720 & 0.695 & 0.437 \\
\hline Total observations & 169 & 95 & \\
\hline
\end{tabular}

Notes: The table compares municipalities with and without weather stations. Significance levels: ${ }^{*} p<0.1,{ }^{* *} p<0.05,{ }^{* * *} p<0.01$. 
Table A4: Public funds and corruption: excluding municipalities in which rainfall is interpolated

\begin{tabular}{|c|c|c|c|c|c|}
\hline & \multicolumn{2}{|c|}{ OLS } & \multicolumn{2}{|c|}{ IV } & \multirow{2}{*}{$\frac{\text { IV-Poisson }}{(5)}$} \\
\hline & $\begin{array}{c}(1) \\
\text { BNAA }\end{array}$ & $\begin{array}{c}(2) \\
\text { BNAA }\end{array}$ & $\begin{array}{c}(3) \\
\text { BNAA }\end{array}$ & $\begin{array}{c}(4) \\
\text { BNAA }\end{array}$ & \\
\hline log funds per cap & $\begin{array}{l}0.420^{* *} \\
(0.162)\end{array}$ & $\begin{array}{l}0.435^{* *} \\
(0.166)\end{array}$ & $\begin{array}{l}1.161^{* *} \\
(0.481)\end{array}$ & $\begin{array}{l}1.205^{* *} \\
(0.476)\end{array}$ & $\begin{array}{l}0.947^{* * *} \\
(0.330)\end{array}$ \\
\hline Geography & $\checkmark$ & $\checkmark$ & $\checkmark$ & $\checkmark$ & $\checkmark$ \\
\hline Economic conditions & $\checkmark$ & $\checkmark$ & $\checkmark$ & $\checkmark$ & $\checkmark$ \\
\hline Civil society & $\checkmark$ & $\checkmark$ & $\checkmark$ & $\checkmark$ & $\checkmark$ \\
\hline Composition of local gov. & & $\checkmark$ & & $\checkmark$ & $\checkmark$ \\
\hline $\begin{array}{l}\text { F-stat. } \\
\text { rainfall \% deviation, } 30 \% \text { cutoff }\end{array}$ & & & $\begin{array}{c}7.222 \\
1.087 \\
(0.405)\end{array}$ & $\begin{array}{c}7.617 \\
1.083 \\
(0.392)\end{array}$ & \\
\hline $\begin{array}{l}\text { R-sq } \\
\text { Number of observations }\end{array}$ & $\begin{array}{l}0.238 \\
88\end{array}$ & $\begin{array}{l}0.304 \\
88\end{array}$ & 88 & 88 & 88 \\
\hline
\end{tabular}

Notes: Regional dummies are included in all specifications. Robust standard errors are in parentheses. Last column reports marginal effects from an IV-Poisson regression. Significance levels: ${ }^{*} p<0.1,{ }^{* *} p<0.05$, *** $p<0.01$. 
Table A5: Endogeneity of weather stations

\begin{tabular}{|c|c|c|c|}
\hline \multirow[t]{2}{*}{ Control of baseline reg. } & \multicolumn{2}{|c|}{ Mean } & \multirow[t]{2}{*}{$t-s t a t$} \\
\hline & closed after 89 & exists today & \\
\hline BNAA & 0.686 & 0.926 & -1.435 \\
\hline funds per capita & 39.093 & 30.309 & 1.499 \\
\hline rainfall $\%$ deviation, $30 \%$ cutoff & 1.065 & 1.097 & -0.788 \\
\hline rainfall $\%$ deviation, $50 \%$ cutoff & 1.396 & 1.432 & -0.591 \\
\hline historical rainfall, $\mathrm{mm}$ & 673.649 & 663.608 & 0.747 \\
\hline \multicolumn{4}{|l|}{ Geography } \\
\hline distance to BNAA regional center & 71.106 & 74.731 & -0.733 \\
\hline elevation & 476.988 & 488.713 & -0.209 \\
\hline relief slope & 7.427 & 7.250 & 0.250 \\
\hline longitude & 42.886 & 42.759 & 1.189 \\
\hline latitude & 24.896 & 25.177 & -1.213 \\
\hline settlements near water & 5.860 & 9.505 & $-2.764^{* *}$ \\
\hline \multicolumn{4}{|l|}{ Economic conditions } \\
\hline log muncipal income per capita & 5.418 & 5.446 & -0.914 \\
\hline unemployment & 21.990 & 18.310 & $2.747^{* * *}$ \\
\hline net privatization income & 4.094 & 3.939 & 0.139 \\
\hline \multicolumn{4}{|l|}{ Civil society } \\
\hline newspaper circ. per capita & 166.450 & 74.465 & $2.836^{* * *}$ \\
\hline share university degree & 0.060 & 0.089 & $-5.290^{* * *}$ \\
\hline share urban population & 0.910 & 0.560 & 0.970 \\
\hline voter turnout 2003 & 0.751 & 0.430 & 1.603 \\
\hline \multicolumn{4}{|l|}{ Composition of local gov. } \\
\hline mayor triple coal. & 0.686 & 0.644 & 0.610 \\
\hline council majority triple coal. & 0.500 & 0.416 & 1.150 \\
\hline mayor \& council triple coal. & 0.419 & 0.297 & $1.739^{*}$ \\
\hline mayor MRF & 0.151 & 0.119 & 0.645 \\
\hline council majority MRF & 0.140 & 0.079 & 1.330 \\
\hline mayor\&council MRF & 0.116 & 0.069 & 1.111 \\
\hline \multicolumn{4}{|l|}{ Mayor characteristics } \\
\hline margin elected 2003 & 0.071 & 0.079 & -0.808 \\
\hline in politics before 2003 & 0.729 & 0.683 & 0.686 \\
\hline Total observations & 86 & 101 & \\
\hline
\end{tabular}

Notes: The table compares municipalities in which there was a weather station before 1989 (which no longer exists) with those in which there was a station both before and after 1989. Significance levels: ${ }^{*} p<0.1,{ }^{* *} p<0.05,{ }^{* * *} p<0.01$. 
Table A6: Public funds and corruption: Robustness 1

\begin{tabular}{|c|c|c|c|c|c|}
\hline & \multicolumn{4}{|c|}{ IV } & \multirow{2}{*}{$\begin{array}{c}\text { OLS } \\
(5) \\
\text { BNAA }\end{array}$} \\
\hline & $\begin{array}{l}(1) \\
\text { BNAA through pca }\end{array}$ & $\begin{array}{c}(2) \\
\text { PFIA }\end{array}$ & $\begin{array}{c}(3) \\
\text { BNAA }\end{array}$ & $\begin{array}{c}(4) \\
\text { BNAA }\end{array}$ & \\
\hline $\log$ funds per cap & $\begin{array}{r}0.478^{*} \\
(0.264)\end{array}$ & $\begin{array}{c}2.575 \\
(1.792)\end{array}$ & $\begin{array}{l}0.755^{* * *} \\
(0.268)\end{array}$ & $\begin{array}{l}0.827^{* *} \\
(0.339)\end{array}$ & $\begin{array}{l}0.261^{* * *} \\
(0.0903)\end{array}$ \\
\hline margin elected 2003 & & & $\begin{array}{c}-1.584 \\
(1.011)\end{array}$ & & \\
\hline in politics before 2003 & & & $\begin{array}{c}0.0258 \\
(0.176)\end{array}$ & & \\
\hline Geography & $\checkmark$ & $\checkmark$ & $\checkmark$ & $\checkmark$ & $\checkmark$ \\
\hline Economic conditions & $\checkmark$ & $\checkmark$ & $\checkmark$ & $\checkmark$ & $\checkmark$ \\
\hline Civil society & $\checkmark$ & $\checkmark$ & $\checkmark$ & $\checkmark$ & $\checkmark$ \\
\hline Composition of local gov. & $\checkmark$ & $\checkmark$ & $\checkmark$ & $\checkmark$ & $\checkmark$ \\
\hline $\begin{array}{l}\text { F-stat. } \\
\text { rainfall \% deviation, } 30 \% \text { cutoff }\end{array}$ & $\begin{array}{c}18.52 \\
1.127 \\
(0.262)\end{array}$ & $\begin{array}{c}12.58 \\
0.922 \\
(0.260)\end{array}$ & $\begin{array}{c}19.09 \\
1.158 \\
(0.265)\end{array}$ & 20.34 & \\
\hline rainfall $\%$ deviation, $50 \%$ cutoff & & & & $\begin{array}{c}0.641 \\
(0.142)\end{array}$ & \\
\hline $\begin{array}{l}\text { Number of observations } \\
\mathrm{N}\end{array}$ & 225 & 254 & 225 & 225 & $\begin{array}{l}0.215 \\
225\end{array}$ \\
\hline
\end{tabular}

Notes: Regional dummies are included in all specifications. Robust standard errors are in parentheses. Significance levels: ${ }^{*} p<0.1, * * p<0.05, * * * p<0.01$. 
Table A7: Public funds and corruption: LiTS 2006 results

\begin{tabular}{|c|c|c|c|c|}
\hline & $\begin{array}{l}\text { (1) } \\
\text { Corr. rel. to } 1989\end{array}$ & $\begin{array}{l}\quad(2) \\
\text { Trust inst. }\end{array}$ & $\begin{array}{l}(3) \\
\text { trust in people today }\end{array}$ & $\begin{array}{c}(4) \\
\text { trust in people today }\end{array}$ \\
\hline log funds per cap & $\begin{array}{l}-0.405^{* * *} \\
(0.153)\end{array}$ & $\begin{array}{l}0.339^{* *} \\
(0.172)\end{array}$ & $\begin{array}{l}0.660^{* *} \\
(0.278)\end{array}$ & $\begin{array}{l}0.900^{* * *} \\
(0.303)\end{array}$ \\
\hline trust in people before 1989 & & & & $\begin{array}{l}0.154^{* * *} \\
(0.0459)\end{array}$ \\
\hline Respondent characteristics & $\checkmark$ & $\checkmark$ & $\checkmark$ & $\checkmark$ \\
\hline Geography & $\checkmark$ & $\checkmark$ & $\checkmark$ & $\checkmark$ \\
\hline Economic conditions & $\checkmark$ & $\checkmark$ & $\checkmark$ & $\checkmark$ \\
\hline Civil society & $\checkmark$ & $\checkmark$ & $\checkmark$ & $\checkmark$ \\
\hline Composition of local gov. & $\checkmark$ & $\checkmark$ & $\checkmark$ & $\checkmark$ \\
\hline F-stat. & 138.0 & 188.5 & 171.8 & 145.6 \\
\hline rainfall $\%$ deviation, $30 \%$ cutoff & $\begin{array}{c}1.785 \\
(0.152)\end{array}$ & $\begin{array}{c}1.831 \\
(0.133)\end{array}$ & $\begin{array}{c}1.790 \\
(0.137)\end{array}$ & $\begin{array}{c}1.778 \\
(0.147)\end{array}$ \\
\hline Number of observations & 787 & 906 & 915 & 811 \\
\hline
\end{tabular}


Table A8: Public funds and corruption: Heterogeneous effects

\begin{tabular}{|c|c|c|c|c|c|c|}
\hline & \multicolumn{2}{|c|}{ log mun.inc. per cap } & \multicolumn{2}{|c|}{ unemployment } & \multicolumn{2}{|c|}{ newspapers circ. } \\
\hline & $\begin{array}{c}<\text { median } \\
(1) \\
\text { BNAA }\end{array}$ & $\begin{array}{c}>=\underset{(2)}{\operatorname{median}} \\
\text { BNAA }\end{array}$ & $\begin{array}{c}<\text { median } \\
(3) \\
\text { BNAA }\end{array}$ & $\begin{array}{c}>=\underset{(4)}{\text { median }} \\
\text { BNAA }\end{array}$ & $\begin{array}{c}<\text { median } \\
(5) \\
\text { BNAA }\end{array}$ & $\begin{array}{c}>=\text { median } \\
(6) \\
\text { BNAA }\end{array}$ \\
\hline $\log$ funds per cap & $\begin{array}{c}0.500 \\
(0.506)\end{array}$ & $\begin{array}{l}0.851^{* * *} \\
(0.287)\end{array}$ & $\begin{array}{l}1.003^{* *} \\
(0.413)\end{array}$ & $\begin{array}{c}-0.00386 \\
(0.331)\end{array}$ & $\begin{array}{l}0.898^{* * *} \\
(0.296)\end{array}$ & $\begin{array}{r}-0.129 \\
(0.510)\end{array}$ \\
\hline Geography & $\checkmark$ & $\checkmark$ & $\checkmark$ & $\checkmark$ & $\checkmark$ & $\checkmark$ \\
\hline Economic conditions & $\checkmark$ & $\checkmark$ & $\checkmark$ & $\checkmark$ & $\checkmark$ & $\checkmark$ \\
\hline Civil society & $\checkmark$ & $\checkmark$ & $\checkmark$ & $\checkmark$ & $\checkmark$ & $\checkmark$ \\
\hline Composition of local gov. & $\checkmark$ & $\checkmark$ & $\checkmark$ & $\checkmark$ & $\checkmark$ & $\checkmark$ \\
\hline $\begin{array}{l}\text { F-stat. } \\
\text { rainfall \% deviation, } 30 \% \text { cutoff }\end{array}$ & $\begin{array}{l}6.615 \\
0.881^{* *} \\
(0.343)\end{array}$ & $\begin{array}{l}12.35 \\
1.350^{* * *} \\
(0.384)\end{array}$ & $\begin{array}{l}11.19 \\
1.015^{* *} \\
(0.303)\end{array}$ & $\begin{array}{l}5.554 \\
1.285^{* *} \\
(0.545)\end{array}$ & $\begin{array}{c}19.39 \\
1.731^{* * *} \\
(0.393)\end{array}$ & $\begin{array}{l}4.048 \\
0.699^{* *} \\
(0.348)\end{array}$ \\
\hline Number of observations & 113 & 112 & 117 & 108 & 118 & 107 \\
\hline
\end{tabular}

Notes: Regional dummies are included in all specifications. Robust standard errors are in parentheses. Significance levels: $p<0.1,{ }^{* *} p<0.05, * * * p<0.01$. 
Table A9: Public funds and corruption: Robustness 2

\begin{tabular}{|c|c|c|c|}
\hline & $\begin{array}{c}(1) \\
\text { BNAA }\end{array}$ & $\begin{array}{c}(2) \\
\text { BNAA }\end{array}$ & $\begin{array}{c}(3) \\
\text { BNAA }\end{array}$ \\
\hline log funds per cap & $\begin{array}{l}0.852^{* * *} \\
(0.279)\end{array}$ & $\begin{array}{l}0.732^{* * *} \\
(0.272)\end{array}$ & $\begin{array}{l}0.802^{* * *} \\
(0.285)\end{array}$ \\
\hline newspapers per cap. ${ }^{*}$ mayor triple coal. & $\begin{array}{r}0.00208^{* *} \\
(0.000946)\end{array}$ & & \\
\hline newspapers per cap. ${ }^{*}$ council majority triple coal. & $\begin{array}{c}-0.00385 \\
(0.00243)\end{array}$ & & \\
\hline newspapers per cap. ${ }^{*}$ mayor $\&$ council triple coal. & $\begin{array}{c}0.00161 \\
(0.00267)\end{array}$ & & \\
\hline distance to province center & & $\begin{array}{c}0.00481 \\
(0.00385)\end{array}$ & \\
\hline Budget topup per capita, 2003 & & & $\begin{array}{l}-3.778 \\
(7.175)\end{array}$ \\
\hline Constant & $\begin{array}{r}4.570 \\
(11.87)\end{array}$ & $\begin{array}{r}4.413 \\
(11.49)\end{array}$ & $\begin{array}{r}3.585 \\
(12.13)\end{array}$ \\
\hline Geography & $\checkmark$ & $\checkmark$ & $\checkmark$ \\
\hline Economic conditions & $\checkmark$ & $\checkmark$ & $\checkmark$ \\
\hline Civil society & $\checkmark$ & $\checkmark$ & $\checkmark$ \\
\hline Composition of local gov. & $\checkmark$ & $\checkmark$ & $\checkmark$ \\
\hline $\begin{array}{l}\text { F-stat. } \\
\text { rainfall } \% \text { deviation, } 30 \% \text { cutoff }\end{array}$ & $\begin{array}{c}19.70 \\
1.153 \\
(0.260)\end{array}$ & $\begin{array}{c}18.70 \\
1.154 \\
(0.267)\end{array}$ & $\begin{array}{c}17.79 \\
1.125 \\
(0.267)\end{array}$ \\
\hline Number of observations & 225 & 225 & 224 \\
\hline
\end{tabular}

Notes: Regional dummies included in all specifications. Robust standard errors are in parentheses. Significance levels: ${ }^{*} p<0.1,{ }^{* *} p<0.05,{ }^{* * *} p<0.01$. 
Table A10: Difference in corruption measures

\begin{tabular}{|c|c|c|}
\hline & $\begin{array}{l}(1) \\
\text { Corruption difference }\end{array}$ & $\begin{array}{l}(2) \\
\text { Corruption difference }\end{array}$ \\
\hline council majority MRF & $\begin{array}{c}1.139 \\
(0.708)\end{array}$ & \\
\hline mayor\&council MRF & & $\begin{array}{r}1.241^{*} \\
(0.661)\end{array}$ \\
\hline $\log$ funds per cap & $\begin{array}{c}-0.544 \\
(0.550)\end{array}$ & $\begin{array}{c}-0.545 \\
(0.551)\end{array}$ \\
\hline distance to BNAA regional center & $\begin{array}{c}-0.008 \\
(0.006)\end{array}$ & $\begin{array}{c}-0.007 \\
(0.005)\end{array}$ \\
\hline elevation & $\begin{array}{c}-0.001 \\
(0.001)\end{array}$ & $\begin{array}{c}-0.001 \\
(0.001)\end{array}$ \\
\hline relief slope & $\begin{array}{c}0.115 \\
(0.072)\end{array}$ & $\begin{array}{c}0.116 \\
(0.073)\end{array}$ \\
\hline longitude & $\begin{array}{c}-0.392 \\
(0.532)\end{array}$ & $\begin{array}{r}-0.350 \\
(0.519)\end{array}$ \\
\hline latitude & $\begin{array}{c}-0.324 \\
(0.337)\end{array}$ & $\begin{array}{c}-0.323 \\
(0.329)\end{array}$ \\
\hline settlements near water & $\begin{array}{c}-0.017 \\
(0.015)\end{array}$ & $\begin{array}{c}-0.018 \\
(0.015)\end{array}$ \\
\hline log muncipal income per capita & $\begin{array}{c}-0.117 \\
(0.481)\end{array}$ & $\begin{array}{c}-0.081 \\
(0.483)\end{array}$ \\
\hline unemployment & $\begin{array}{c}-0.032 \\
(0.067)\end{array}$ & $\begin{array}{c}-0.032 \\
(0.067)\end{array}$ \\
\hline net privatization income & $\begin{array}{c}0.008 \\
(0.014)\end{array}$ & $\begin{array}{c}0.008 \\
(0.014)\end{array}$ \\
\hline newspaper circ. per capita & $\begin{array}{c}0.000 \\
(0.001)\end{array}$ & $\begin{array}{c}0.000 \\
(0.001)\end{array}$ \\
\hline university degree & $\begin{array}{c}-9.589 \\
(8.659)\end{array}$ & $\begin{array}{c}-9.414 \\
(8.619)\end{array}$ \\
\hline share urban population & $\begin{array}{c}0.505 \\
(0.672)\end{array}$ & $\begin{array}{c}0.520 \\
(0.670)\end{array}$ \\
\hline voter turnout 2003 & $\begin{array}{c}-0.939 \\
(1.170)\end{array}$ & $\begin{array}{c}-0.967 \\
(1.166)\end{array}$ \\
\hline Region dummies & $\checkmark$ & $\checkmark$ \\
\hline R-sq & 0.095 & 0.096 \\
\hline Number of observations & 225 & 225 \\
\hline
\end{tabular}

Notes: Dependent variable is difference between BNAA measure of corruption and PFIA measure of corruption. Regional dummies are included in all specifications. Robust standard errors are in parentheses. Significance levels: $* p<0.1$, ** $p<0.05,{ }^{* * *} p<0.01$. 


\section{Data information}

\section{Dependent variable}

Corruption Index (from the BNAA audit report data) Sums dummies for the spending violations committed by each municipality in 2004 and 2005. BNAA groups the infractions in the following categories:

1. Infringements related to following the procedures and laws for public procurement

- No public procurement procedure (number of municipalities in which recorded: 38)

- No provision for guarantees, no control procedures or building control (number of municipalities in which recorded: 11)

- Not following the system of double signature (both the mayor and chief accountant need to approve contracts) (number of municipalities in which recorded: 10)

2. Infringements related to fund use and reporting

- Payment for activities not listed in the contract (number of municipalities in which recorded: 1)

- Final payment prior to issuing documents certifying that the work has been completed (number of municipalities in which recorded: 6)

- Using the funds for unauthorized works (number of municipalities in which recorded: 3)

- Not returning on time funds that have not been used (number of municipalities in which recorded: 7)

- The value of the building and repair activities exceeds the funds disbursed by the Commission (number of municipalities in which recorded: 2) 
- No control procedures related to using the funds from the Commission (number of municipalities in which recorded: 8)

- No building control; payment without works completed; pre-payment of building and repair activities (number of municipalities in which recorded: 7)

3. Infringements related to reporting how funds were used and preparing reports for each of the repaired objects

- No files were prepared and sent to the Commission and the Ministry of Finance about how the funds were used or returned (if not used); or these files were incomplete (number of municipalities in which recorded: 28)

- Three-month reports to the Commission and the Ministry of Finance were not sent; or were not complete; or were not sent to the oblast governor (number of municipalities in which recorded: 31)

4. Infringements related to following the municipal procedures in relation to the laws about reporting the incurred expenses

- No system for Financial Management and Control exists; infringements related to this system; no financial controller used (number of municipalities in which recorded: 12)

- Inaccurate accounting recording of the funds (number of municipalities in which recorded: 12)

\section{Independent variables}

Log funds per capita Total funds received (in 2004 and 2005) is from the BNAA audit reports. Population is from the 2001 census.

Rainfall Monthly rainfall (in mm) for all 101 weather stations for 2004 and 2005 from the 
National Institute for Meteorology and Hydrology. The interpolated value for each municipality is the inverse distance weighted average of all values measured in stations within a 45 $\mathrm{km}$ radius from the centroid of the municipality. Monthly historical rainfall values are from Koleva and Peneva (1990). See text on how the rainfall variable used in the regressions is calculated.

Ground flood risk Number of settlements within $1 \mathrm{~km}$ of a water body (river, lake or dam; from GIS); elevation (in meters; from National Statistical Institute), slope (from the National Statistical Institute).

Geography Latitude, longitude (both from NSI) and distance to a BNAA regional center (calculated by authors and using data from BNAA).

Economic conditions Log municipal income per capita (in 2000; from UNDP (2002)); unemployment (in 2003, from NSI); net privatization income (in 2003, from NSI).

Media and civil society Local newspaper circulation per capita (in 2004; only available at the oblast level from NSI); share of population with university degree (2003; from NSI); share of urban population (2003; from NSI); voter turnout (voter turnout at the 2003 local elections from the Central Electoral Commission).

Composition of local government and re-election Political affiliation of the mayor and council are from 2003 election data from the Central Electoral Commission. Re-election is from 2007 data from the Central Electoral Commission. One caveat to interpreting the political affiliation data is that some mayors either switched parties after the 2003 elections (mostly from a relatively small party to one of the large parties), or, while independent on paper, were actually supported by a political party. In the former case, we have coded the mayor's most recent political affiliation, while in the latter case, being endorsed by a party was taken as equivalent to party membership. For instance, 127 mayors belonged to the triple coalition on paper, while following our adjustment their numbers increases to 181 (the respective figures for MRF affiliation are 35 and 38, respectively). The results presented in the main text are 
robust to using the original mayor affiliation.

Mayor characteristics Margin elected (2003; Central Electoral Commission); dummy for whether the mayor has any political experience prior to 2003 (internet search).

\section{Additional variables}

Corruption from the PFIA audit reports Sum of PFIA infringements recorded in each municipality. Unlike BNAA, PFIA does not group infractions in categories.

Corruption from LiTS 2006 Constructed from the following question: "There is less corruption now than around 1989" (including five options "Strongly disagree" (1); "Disagree" (2); "Neither disagree nor agree" (3); "Agree" (4); and "Strongly agree" (5))

Budget topup per capita, 2003 Additional ad-hoc funding received by each municipal government from the central government intended to cover budget deficits for 'state affairs', divided by municipal population (2003; Official state newspaper "Darjaven vestnik").

Control variables from LiTS 2006 Respondent age, age squared, household income (proxied by the share of household resources spent on food, an asset index, and the household self-perceived position on a ten-step income ladder), whether the respondent is employed, respondent's education, respondent's father's education, and whether the respondent or any members of his family were part of the former communist party. 